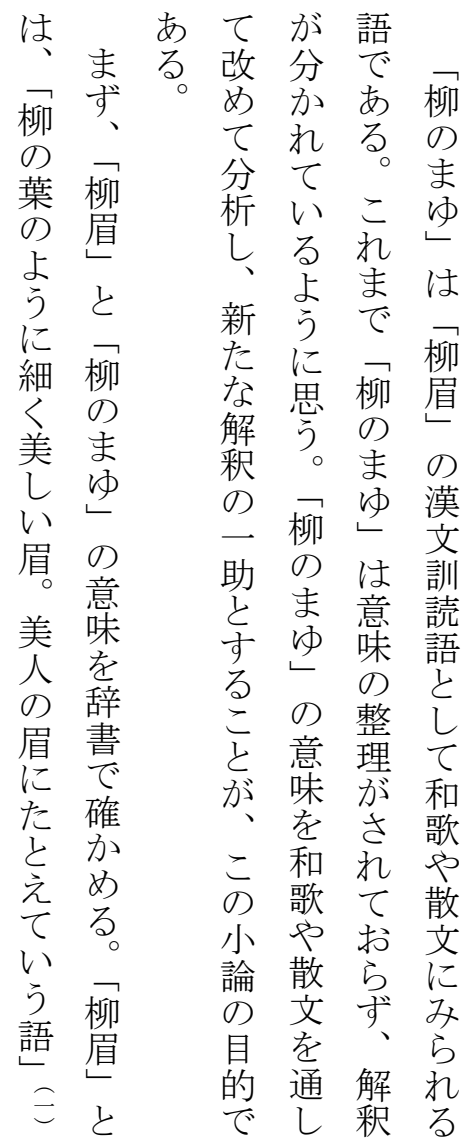

検畫之如れこゆう。見 と 証指何はにはきてる。 法さ涙居る。柳を惖京柳

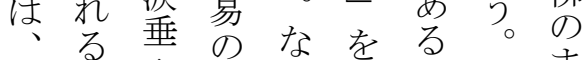

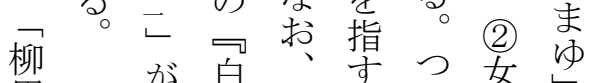

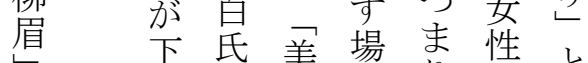
と敷文美合り、の と とき集のと辞ほほ

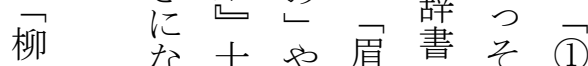
の な士や慁でり柳 まてて ‘をはしの ゆ $心$ 長性指柳た葉 のる恨の方篃美ま

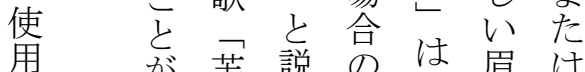
例蓉明二届を柳 を柳如さ通眉柳豈 考の的りをの萌 察偭る㧕る示指葉出 るら如亡亦した出 この眉がれつ芽 各唐多て柳气东

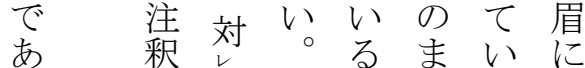

は

組助多 ま 柳 録

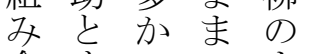

合卞つ宅ま

わるたあゆ

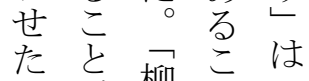

ほが柳气柳

う、有が柳

がことじ意の

味小柳し漢

に論尔ば交

貝まめ訓

を的ゆた読

増でのなと

るる。使まて

考検例は和

え証を歌

る 結 考柳や

果祭届文

楖る眉に

柳艺藏

眉で年やる

藏峁柳語吾市

のまの市

特ゆ市る。

定のなこ

は意首ま

な味っで

占者眉楖

、歌よの

ら゙やうま

れ散なゆ

か 文柳 を

つ通と現

のし結 代

訳て果 語

改的訳

守めにし

るて一た

よ分つ際

も 析 の

灵、意柳

の新にま

複た限ゆ

数な定的

意解た た

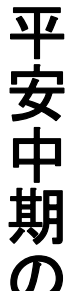

キ 考

柳

の

ま

ゆ 


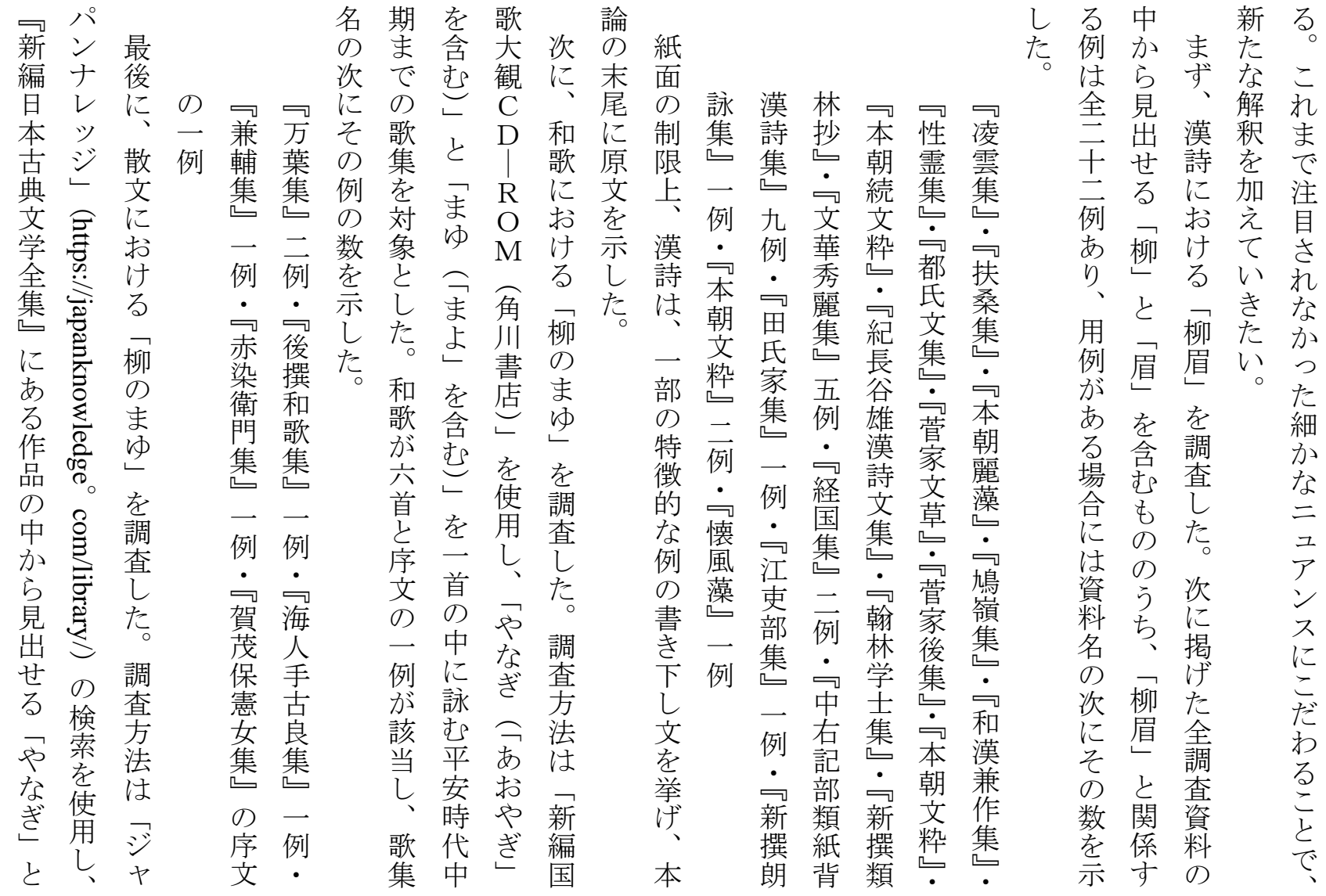
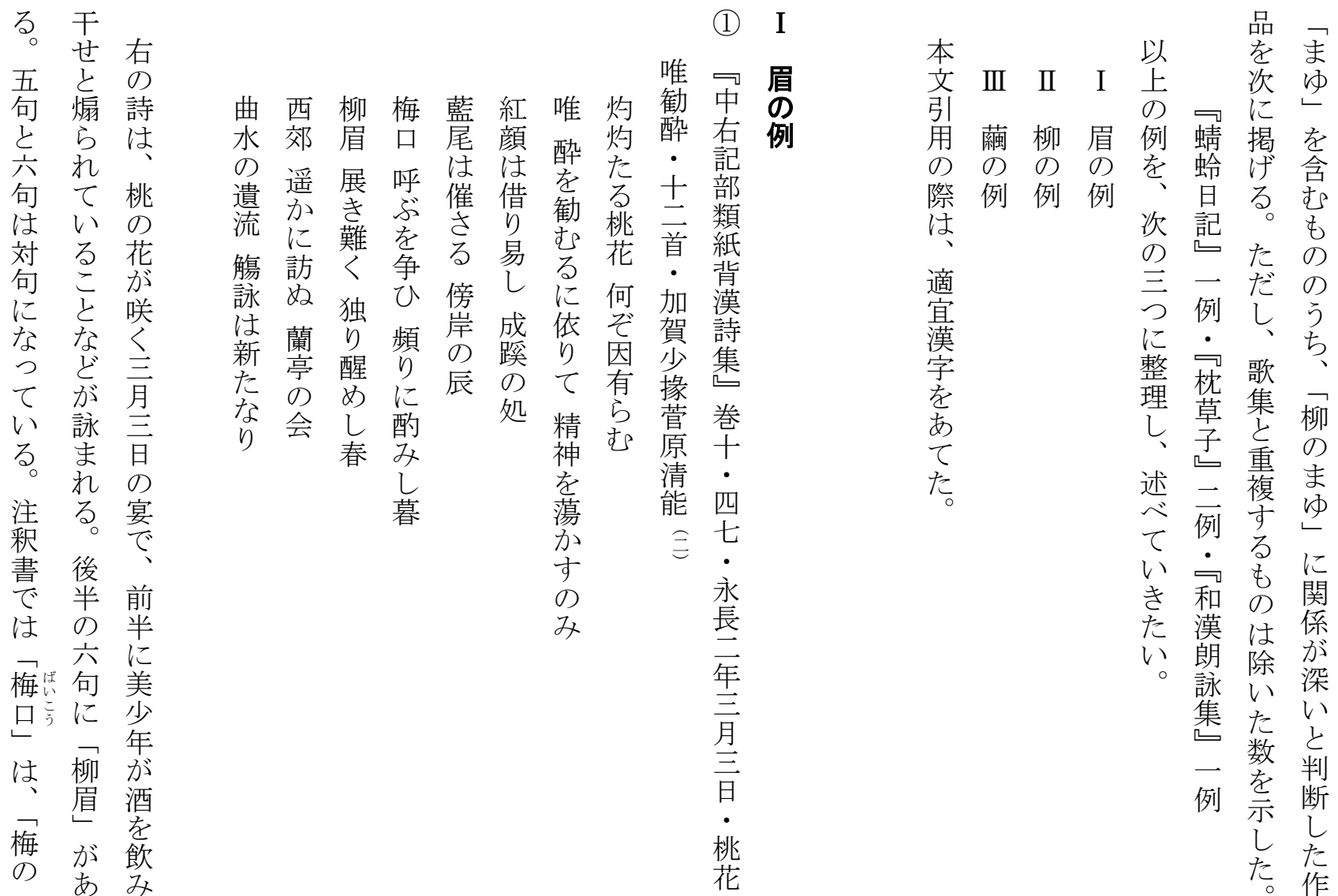

用細柳眉例蜻揭を

ののの皇蛉げ含

際例例例旦るむ

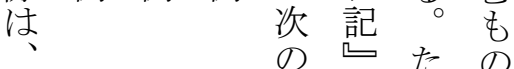

適
漢
字
を
を
た

の たの

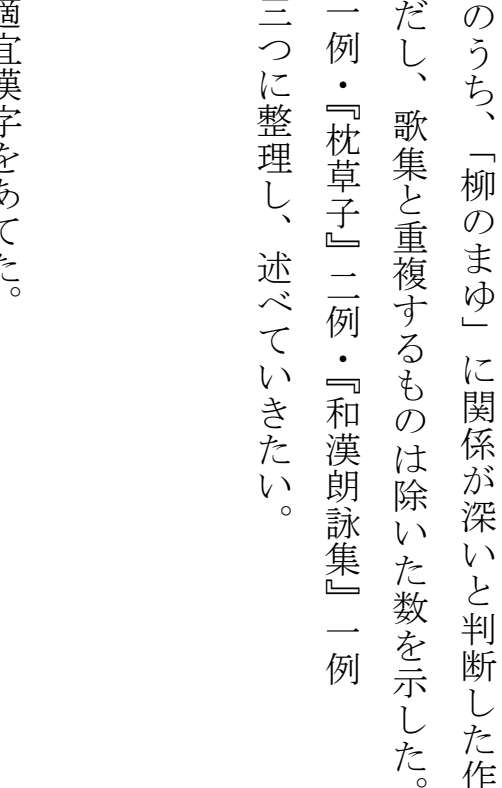


(2)

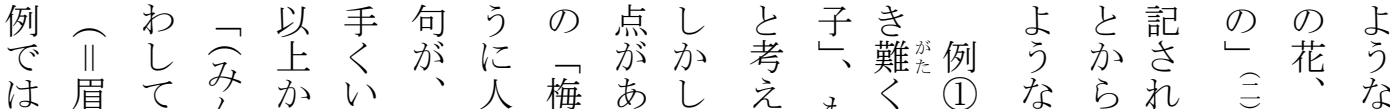
水陪田 は眉てんかい合梅充しえもく 池り 氏

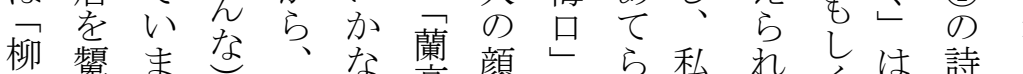
主て家 眉め古子な亭顔々ら私れくは詩

をす注にははの眉はよりお一梅は含く 開る例目な、意例尻 $\neg$ うの部し

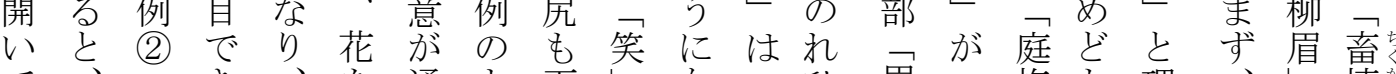

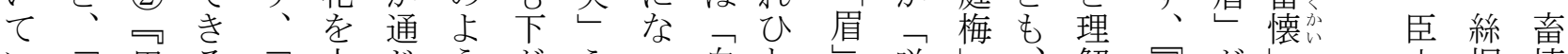

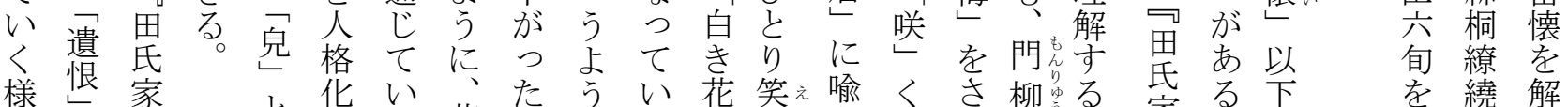
と化い花たうい花笑文喻くさ柳累る家る。下

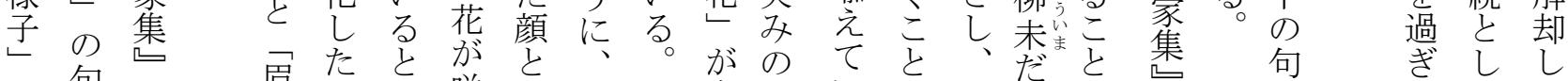

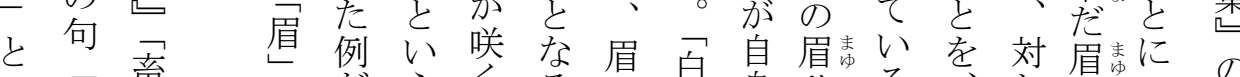

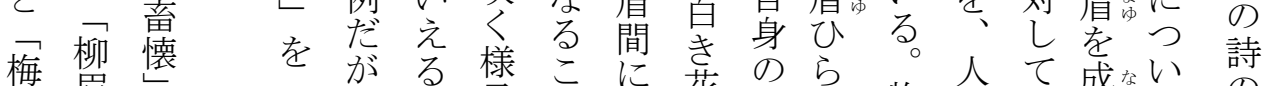

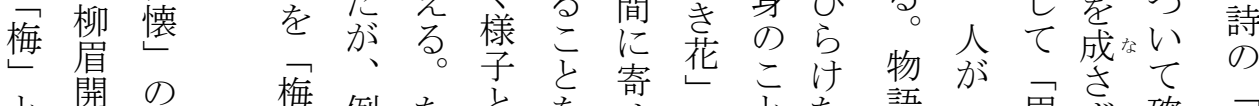

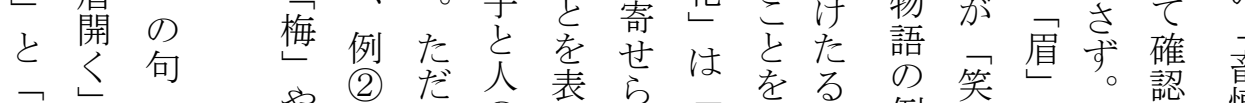

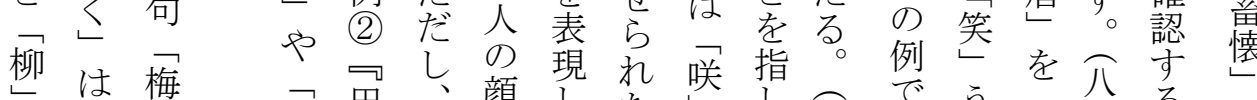

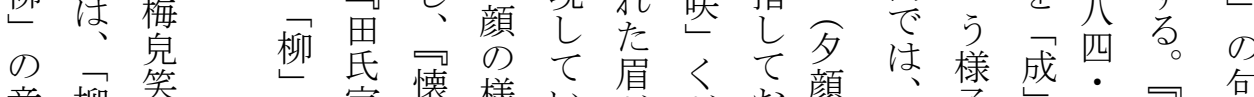

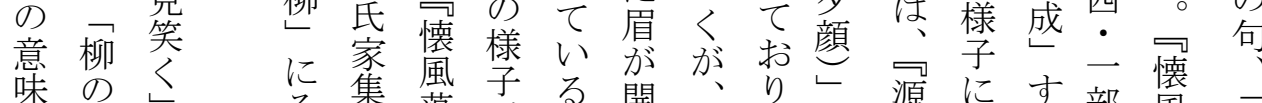
味のに集藻がる開、り、五源にす喻の部風

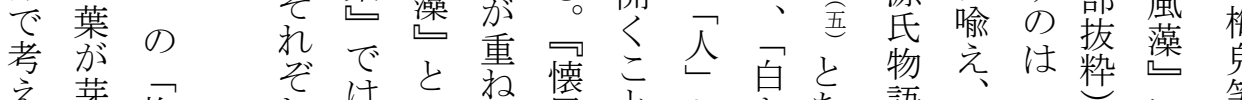

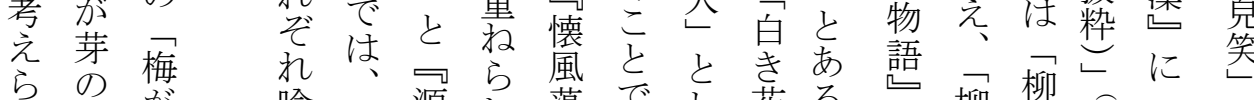

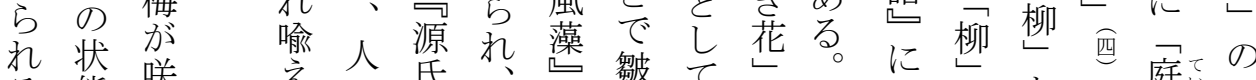

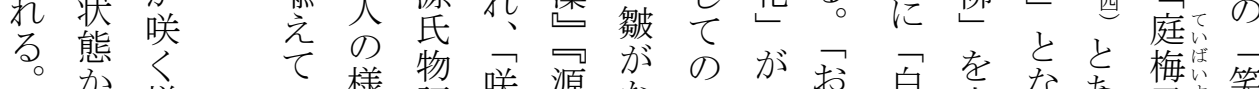

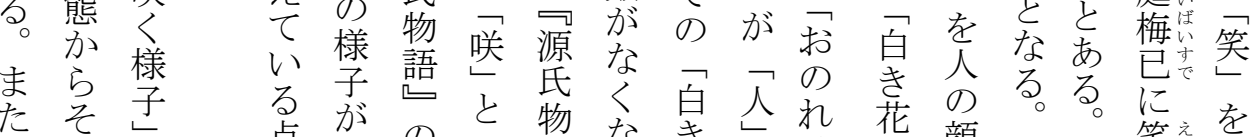

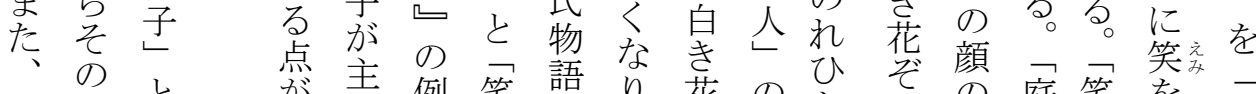
例葉と

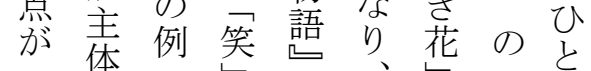
ぞ過 と 遺 五 歌 梅 恨云 代榭鼻 以陪飛く

句 春 羅 遺 は風袖恨 対殊 飄を でに䍃消 あ 合と除 り $\quad$ 七 $\tau$

憒寒 舞 柳 恨栽台眉 の索開 句煦払 


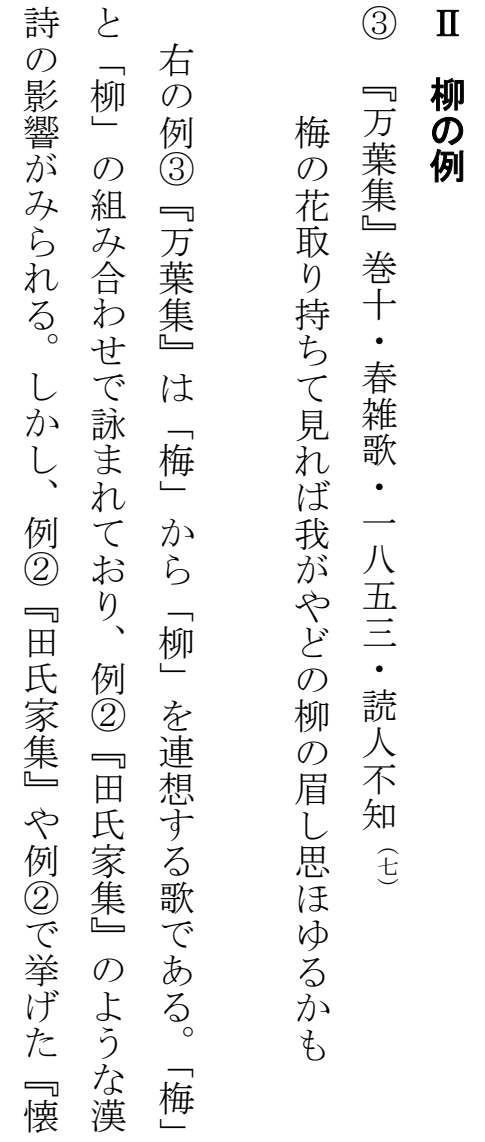

よ

う右

美例春墕

$<$ (4) 白 撰

静を の

加新影池集

な早本染宗

池本占 ほ

は典尘り

何学鏡に春

り 采柳杂

も尔尔四

$\begin{array}{llll}\text { ま } & \text { ま } & \text { ま } \\ \text { 柳 } & \text { ゆ } & \text { よ } & \text { み }\end{array}$

眉春变令

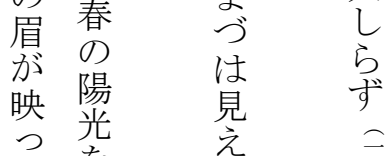

(4) はと出

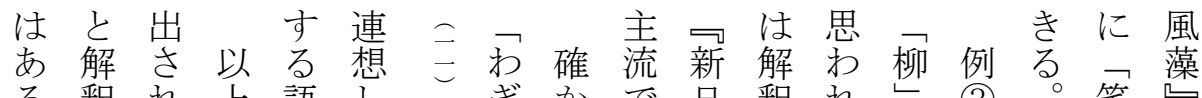

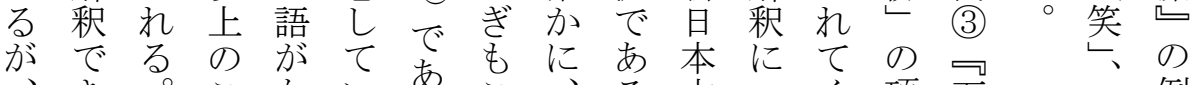

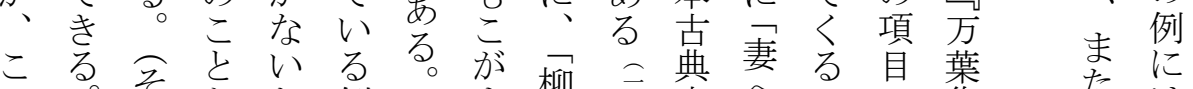

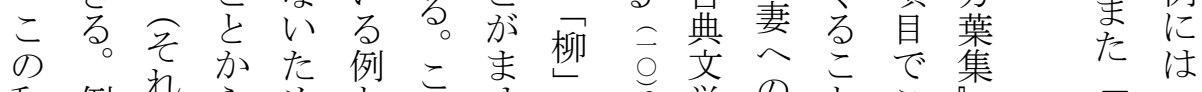

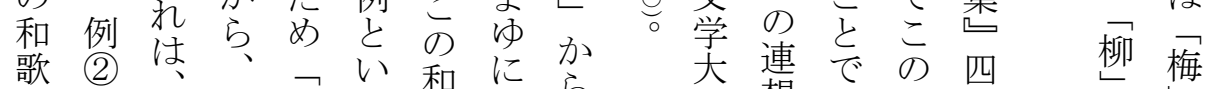
の歌家梅眉え和にら系想あ歌句にに㤵

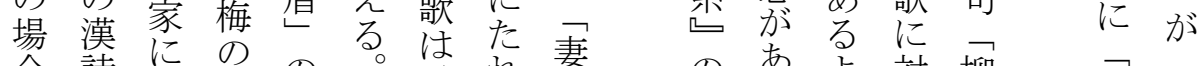
合詩い花意し青ば势 柳見眉手味名柳青思

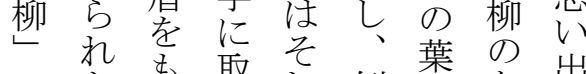
のたも取れ例葉な出 意 梅妻てぼ (3) ら び例 味梅妻見強方々に住

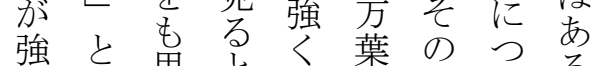
强と思亡な藮葉ける。

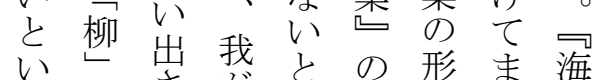
えのさ染思歌に形ま海 る組势家少に似な手 みるの組る柳るみ古 合想る。妻だ良

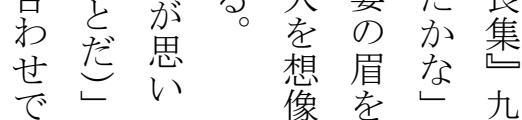

よ る る

う分て眉く

にも立楖に開市

柳机訳㗎年く

のなして眉いだ

まいいののて るが

ゆ无る。う歌 ミ例

をとまな歌し (3)

述た美枕歌恕

とい葉あ斿な集

るし瀵た辞学に

解注の榓 注は

勫㤎顔が慁梅
て萬いこ 


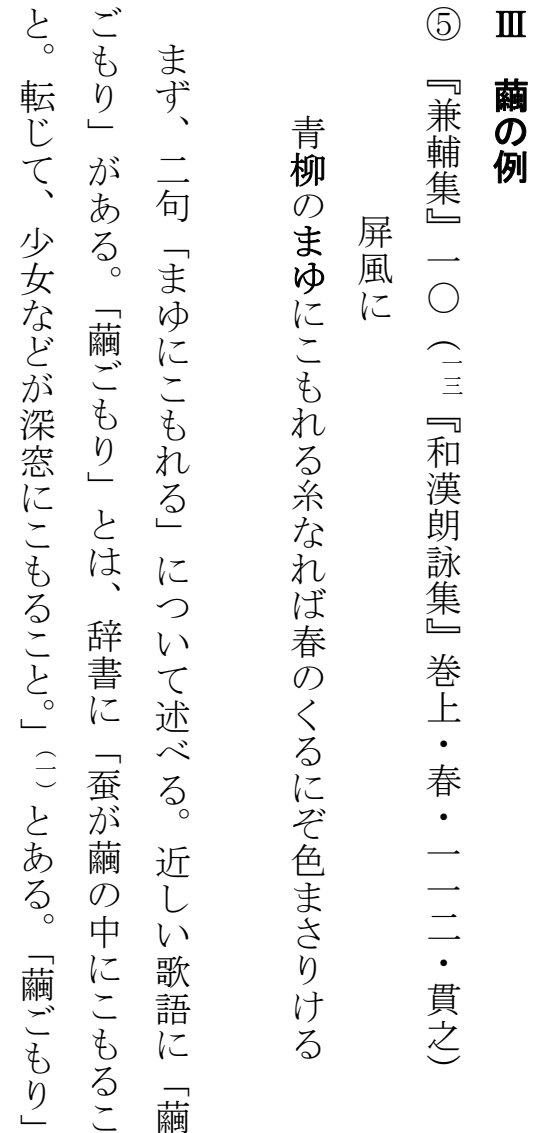

て眉鏡に初る る

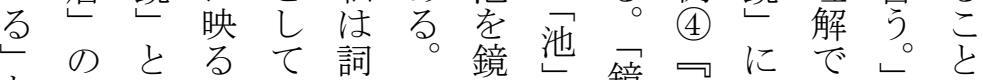

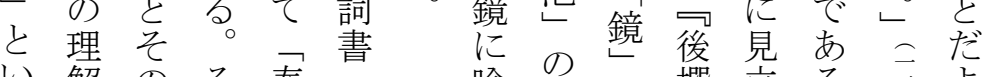
い解のそ春油喻水の撰立る。

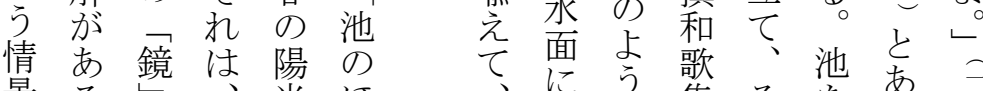
景る 制之な光 ほ

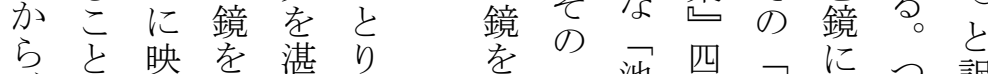

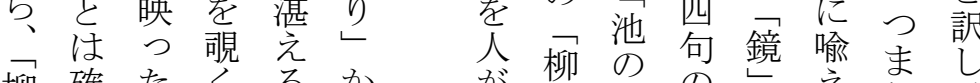
柳確たくくる か が柳 の

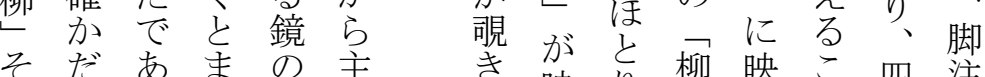
そだあがる ますよ 主速映り柳映こ四注 のがろ ずよ体込っレのると句に

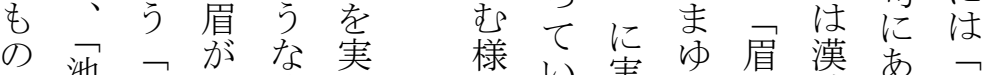
が池眉見池際字い実祭罢詩る 眉 詠ほ のにるる祭はと的る まほをる水あ連考生っなな柳よ れ そ尔

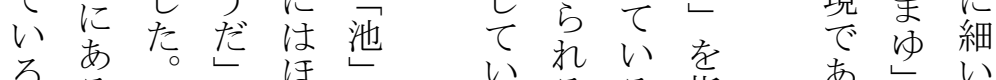

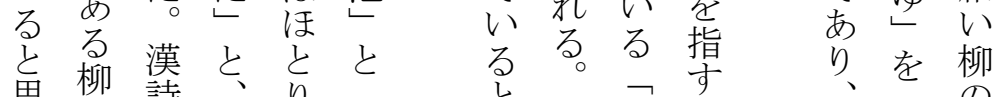

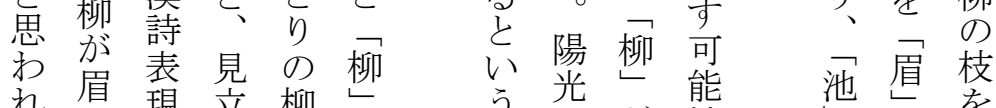

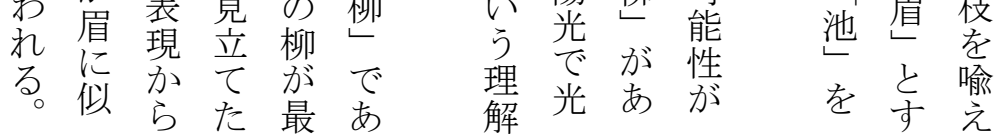

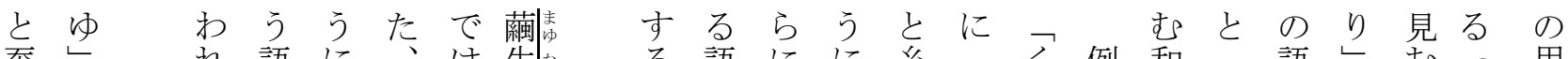

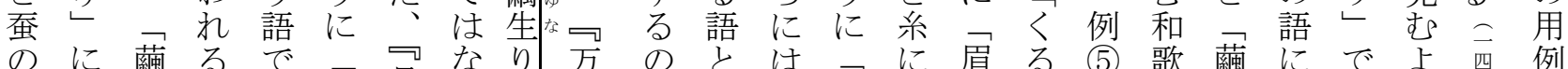
๖ 藏 る

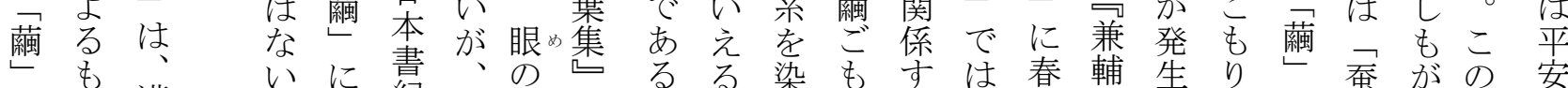
がも 漢 い に 紀

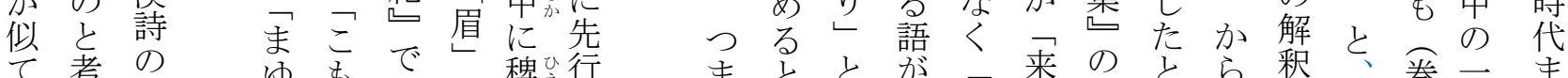

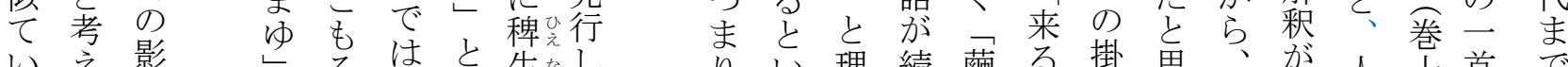

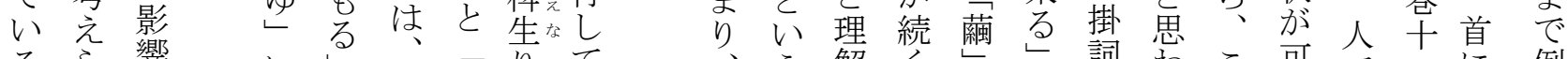
るら 響 に

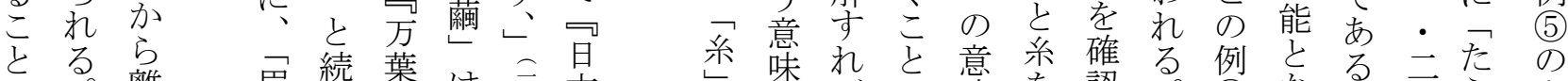
かる。離 眉続葉

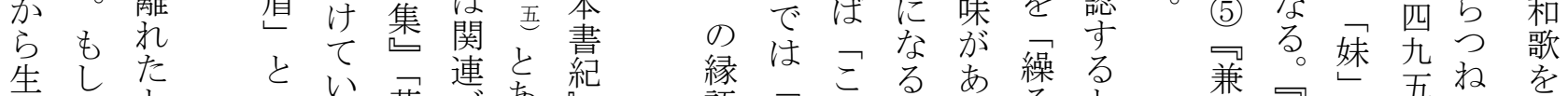

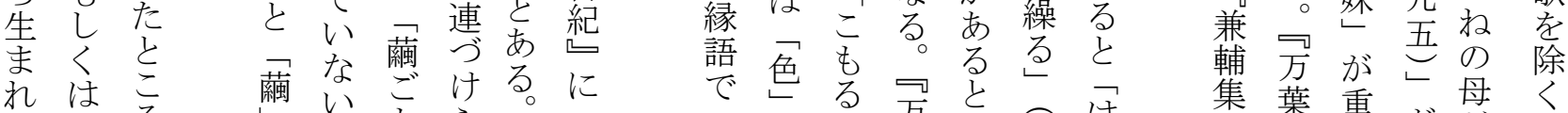

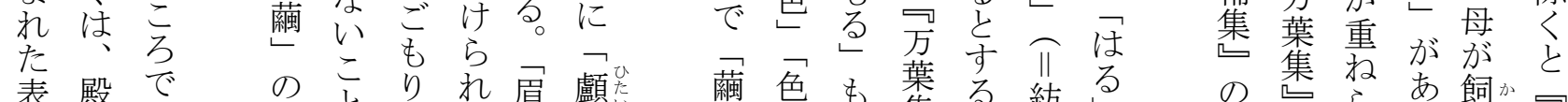

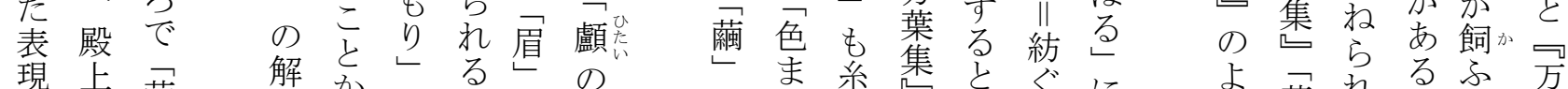

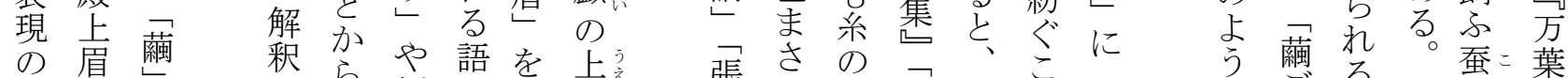

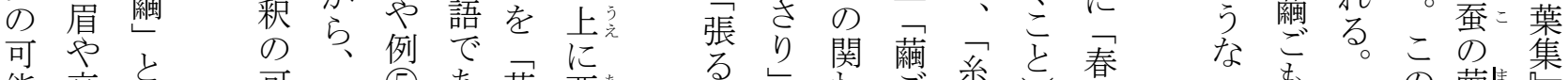

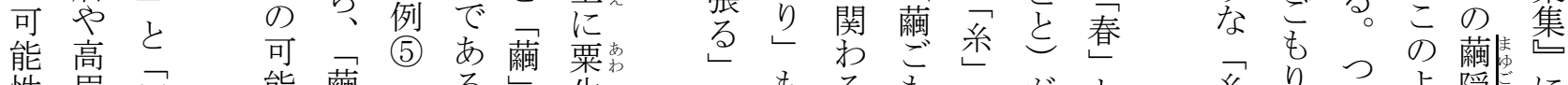
性 眉眉 能藏可 る

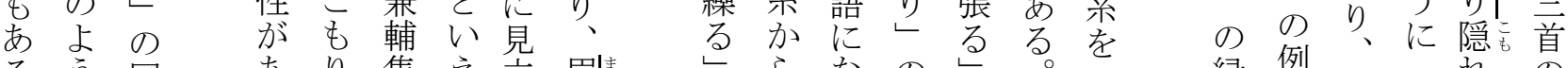

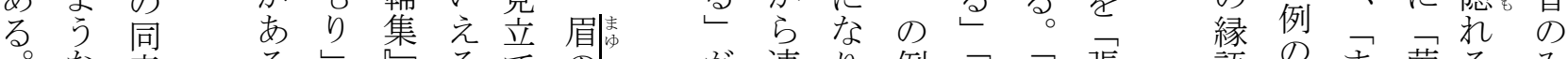

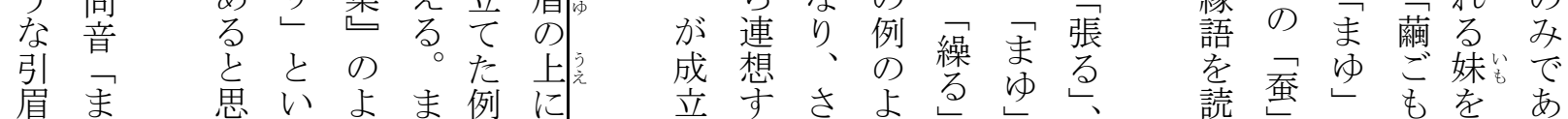




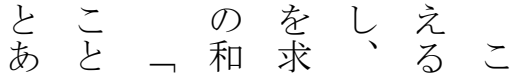

るは柳 歌め後者 の

。明のをら手た場

こ白枝送れ組ち面

のでにり、たみがは

よ文結従道罁道組安

うる。び従綱道組案

漢まけの の分分

詩たる 女邸分年

(1) か 贈ぶ房で練て

(2) ボ

の名てひはを少 9

例すいか適しの の

ににるら 当た試击

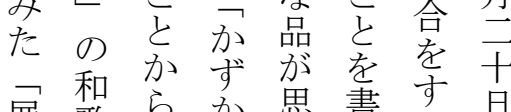

展 和ら㰤思書方旦

くの柳に浮たこ

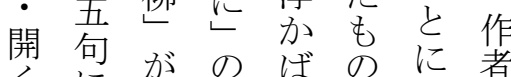

くに之返夺でな帛

ひひ場が山歌るるた

らら場架山る。 兼

こるる る る。の賞に際仕

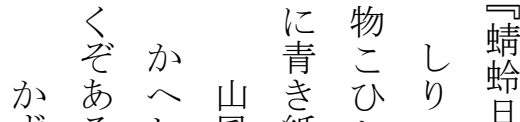

ずるし風紙た间記

ず々ま柳ばか中

にしゔのさた卷

君たこ枝るの

かれそに心゙が安

た どふ結きぎ啝

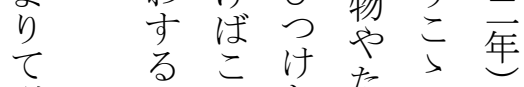

引 市たた斿

な ぼ春り。市あ

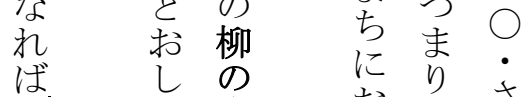

柳 は系衫てざ

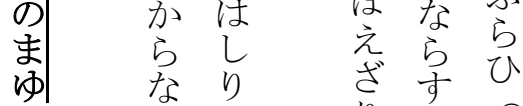

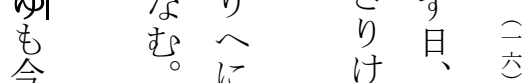

ぞ ひ望亦

ひ占占房

は ばか

か

れ架
色め集よ色葉

々眉浻な濃開上

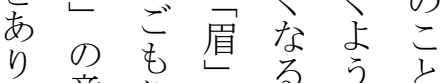

、意りに年に文

系味は対だ藏ら

縁薄例するうこ例

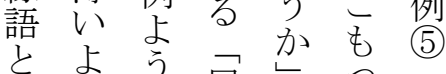

こ う な

思妹间解 い輔

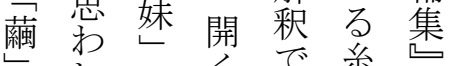

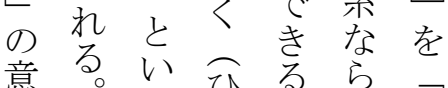

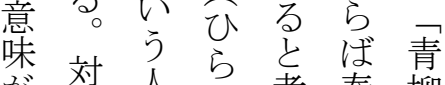

が対人々考春柳

強しのミえがの くて存じる来芽

だ系在がなるこに

和 読くの繰も

歌 張 み歌るつ

とる取まは糸て

いよれた 例のい

え繰な 号 (2) 柳る

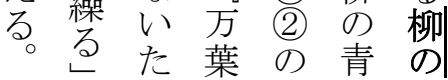

訳 はいし両くそとるる柳解るいいるとすいるき考句が

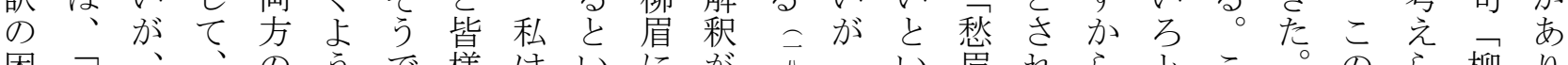

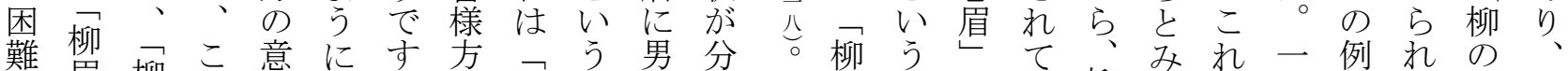

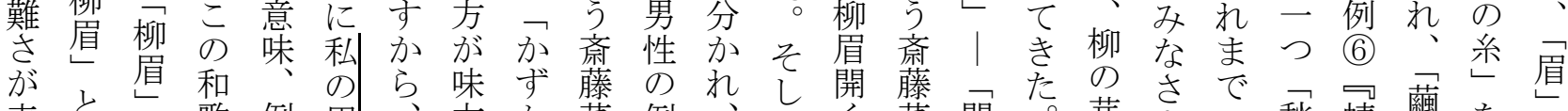

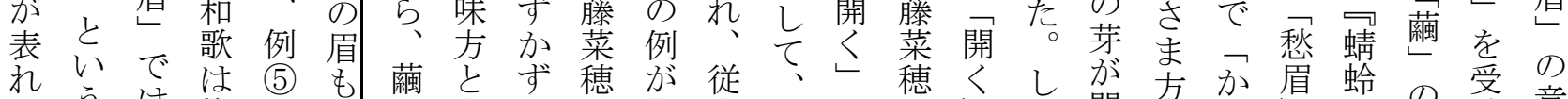

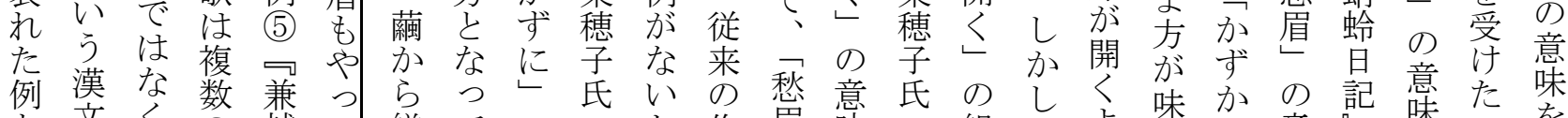

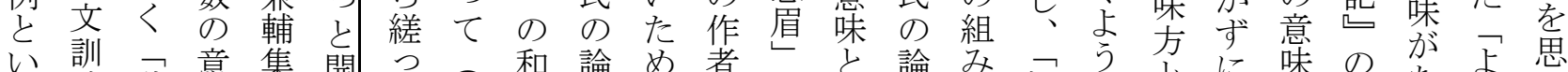
え読愁意隹開った和論め者

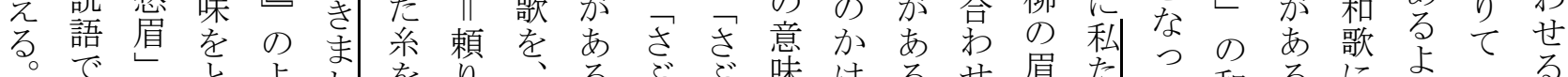

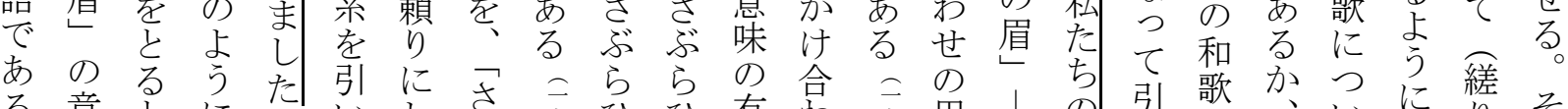

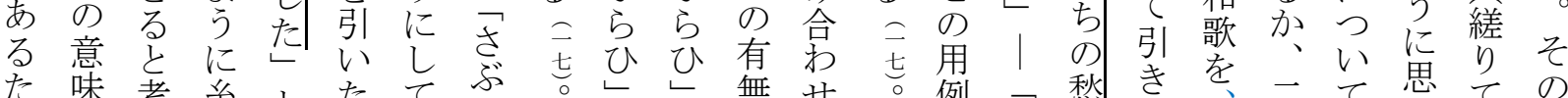

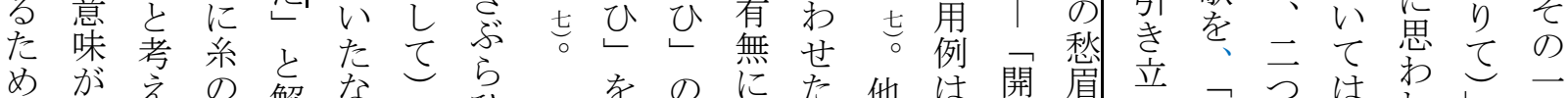

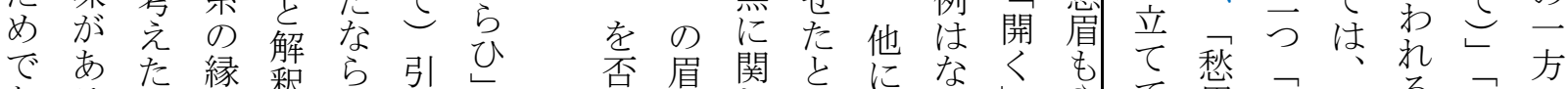

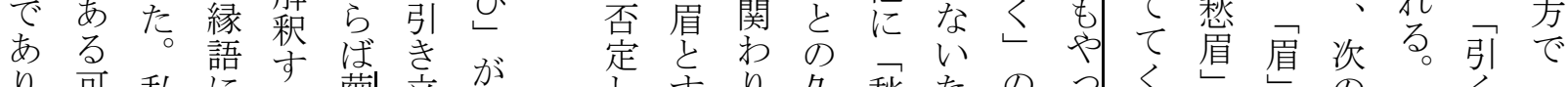

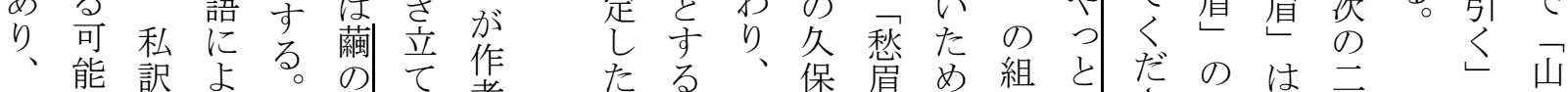

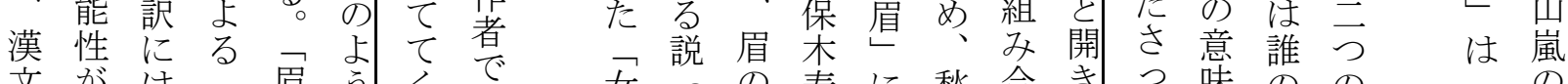

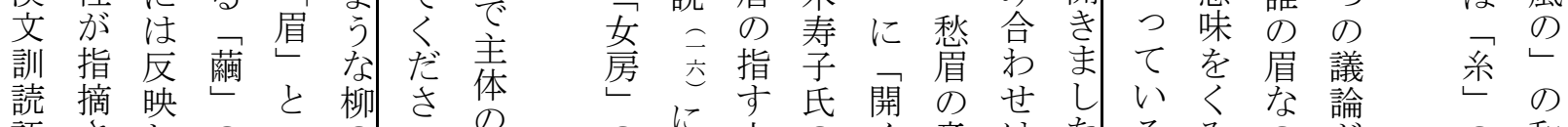

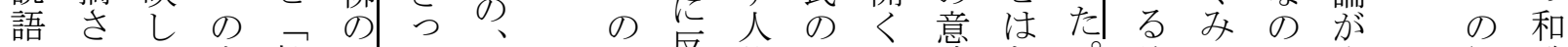

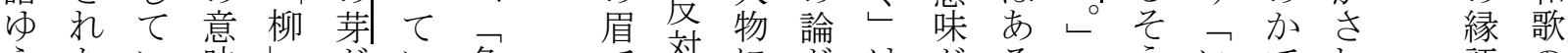
えたい味架い色尽にがはがるこういでれれ語の

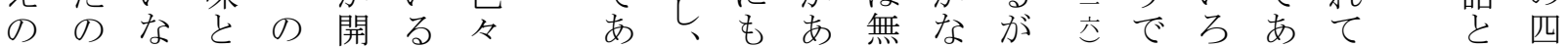




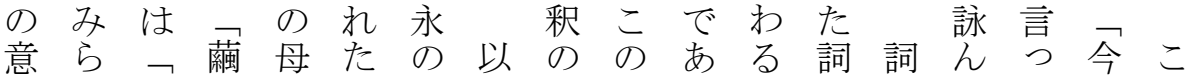
味れまもの母和るっ書書だたはの

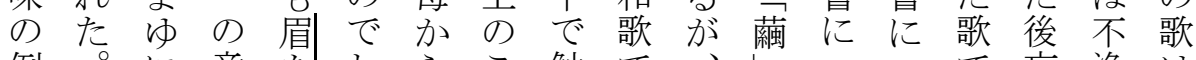

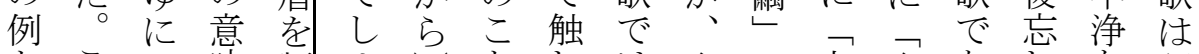

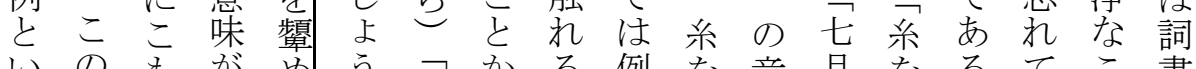

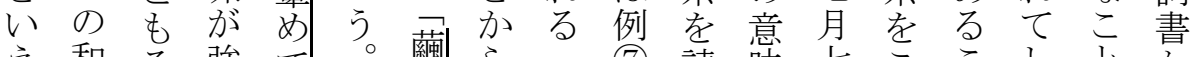
え和る強で 風ら、可 (7) 請味七ここしとか る 歌る こ市てて織引う齐蛉た釈和り分てっ範

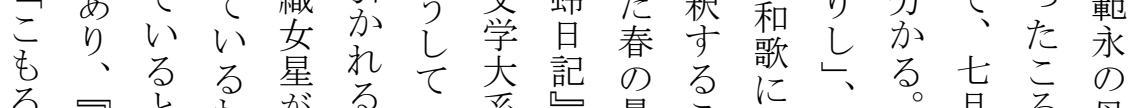

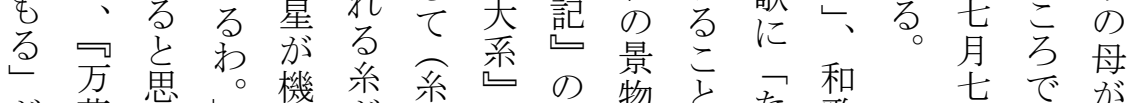

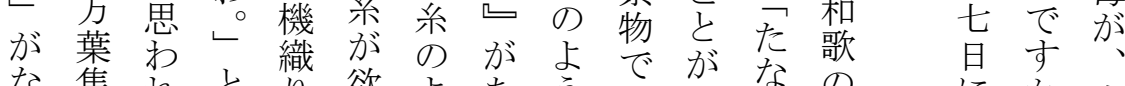

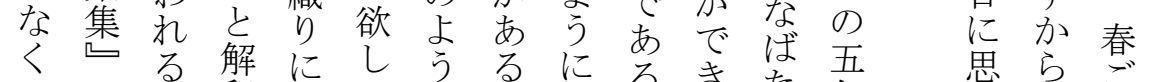

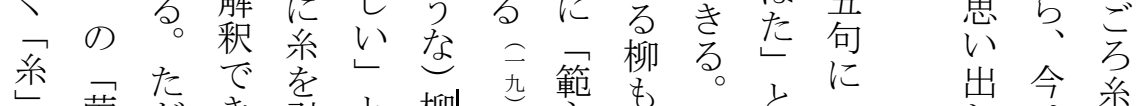

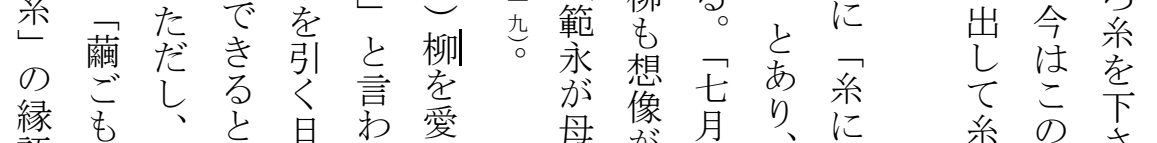

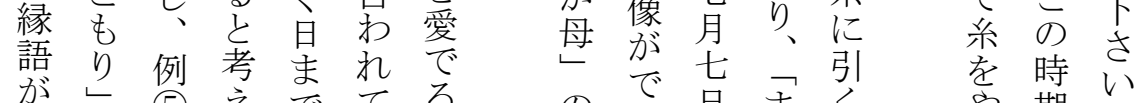
が (5) えでてる

みがる。い春

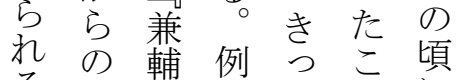

る影集 (5) と と に

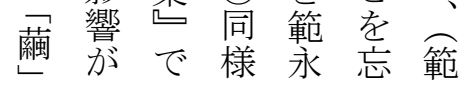

ので早まく 愁るはゆと 眉さ柏を采る 解に秋関ま
る 期文 之過願 らてた のレの でとを、
な

を月と範湋

七七永閔

て旦りが集

柳 思し母

のひこの四

まいら、?

ゆで、春

忘やこ ら赤

れるの系染

して過を荫

けこ望永

ふたた 元

た てり

ばたとを い

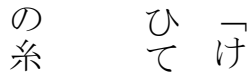

に後 が

ひ忘ら

ま れた

七る

理 解鏡立次す古ら類言は態を広意右は右る。こ

もとてにこい薄似い、かでげでの異ののの

でにた $っ$ と形もの表賀ら枝て理例な序序

き見用眉でと頼言し茂葉をい解 8 8 る文文

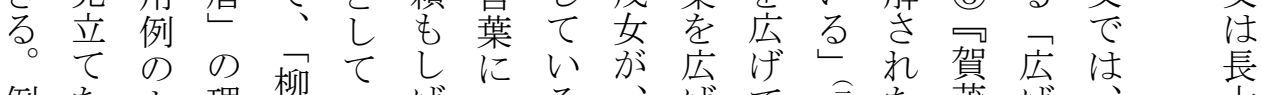

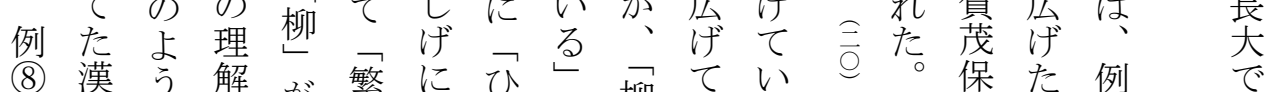

(8) 漢う解が繁に ひ

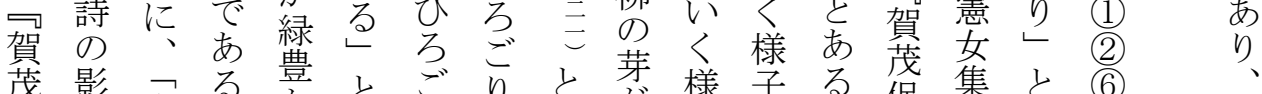

茂影水る豊とごりと芽様子る。保集と (6)

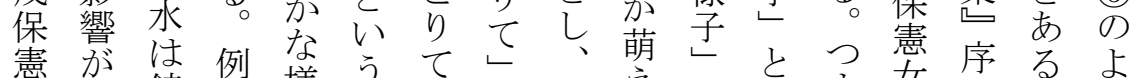

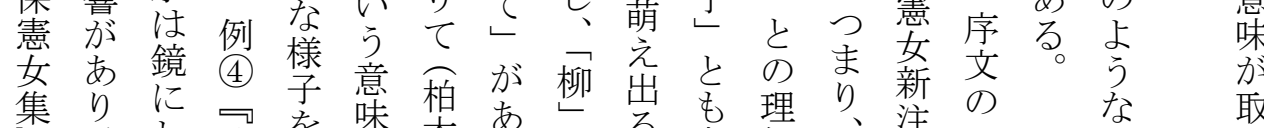

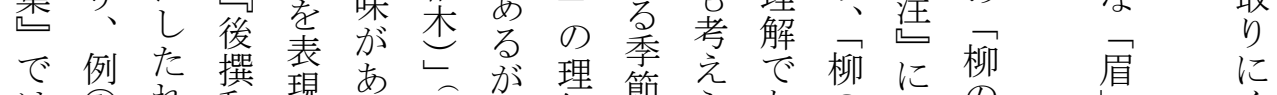

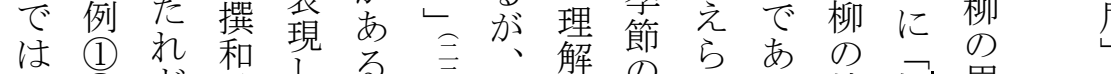

若 $\stackrel{2}{の}$ ど歌た

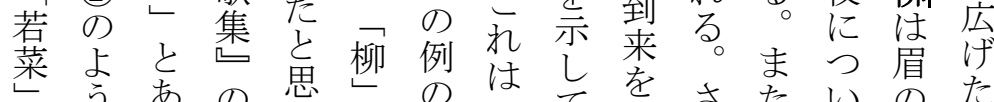

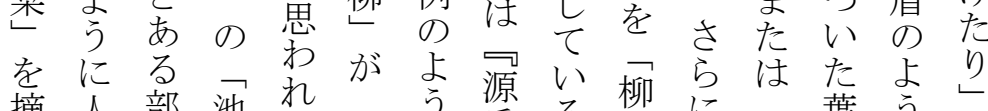

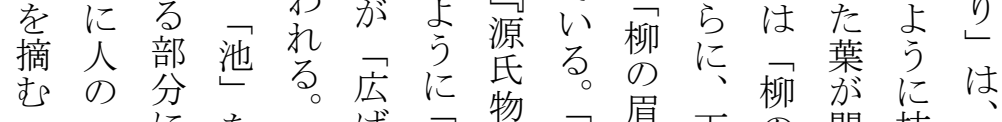

白眉水鏡

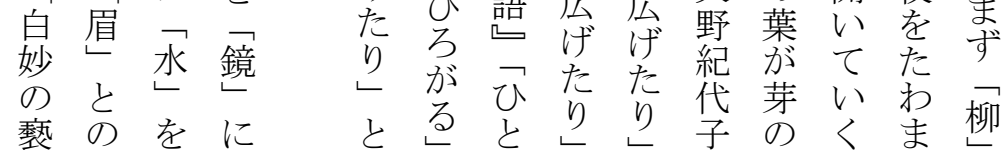

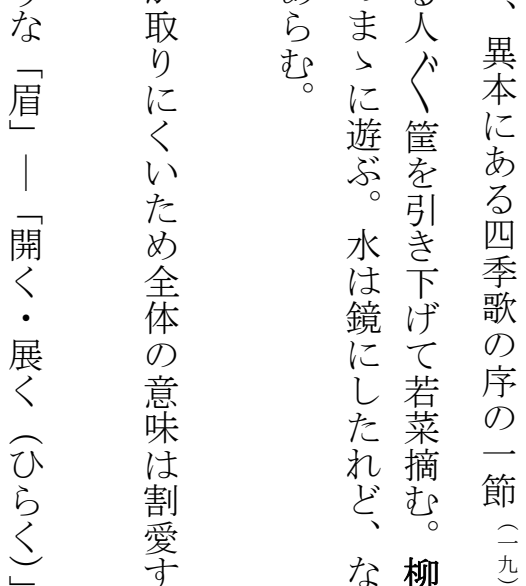


(9) ごげしなががが例状と味以ろううあた け の

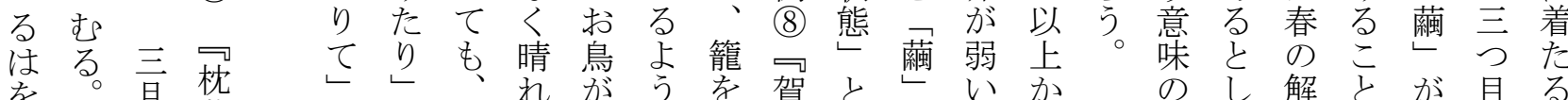

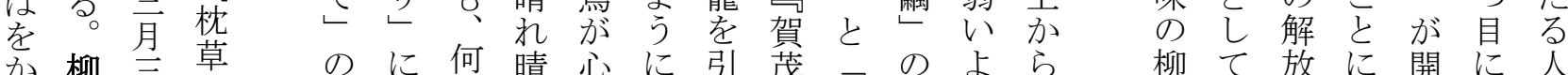

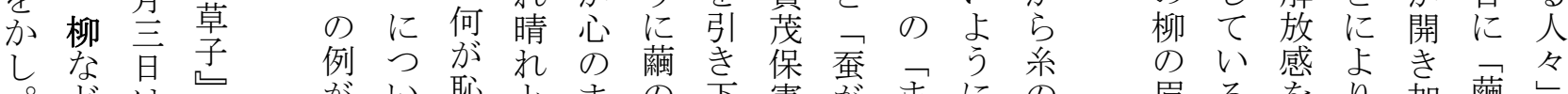

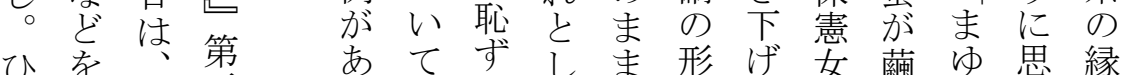

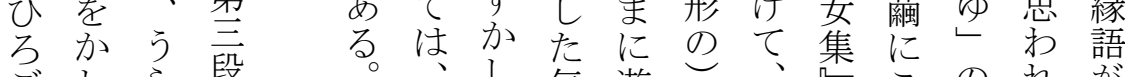

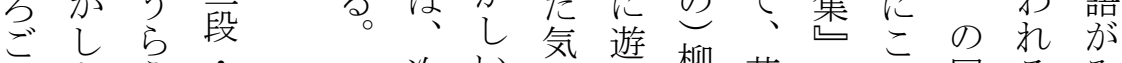
りきう正次い持ぶ柳若序も同るみ

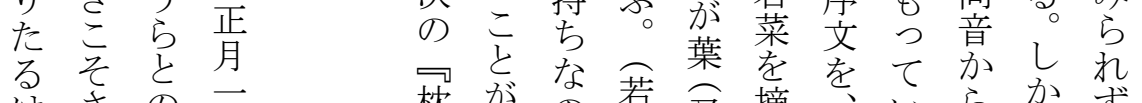

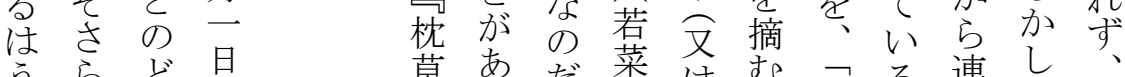
うらど星 たなかは ぞ机照主

見々り

るもる

だ桃

ま 花

ゆの

に今

も咲

りは

たじ

草䒚だ采は赫る連し、 子亏加摘㟚々辺様想例藏

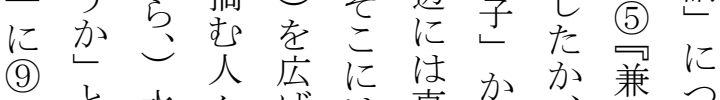

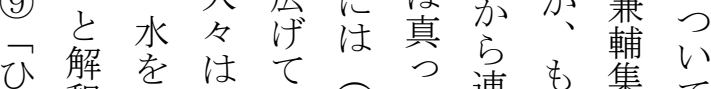
万釈鏡、心若白連も集て ごでの眉る菜な想くでは りるるる每繁摘段たは普触眉 る考に代せ高着能柳た直

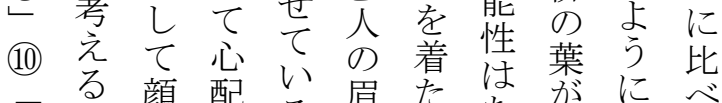
ひ。顔配る睰た劣芽眉て のい感よきき茴々 が。醸、減等が

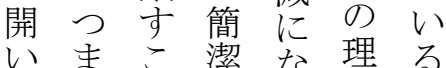
きり、になる解こ た掻な節きあで

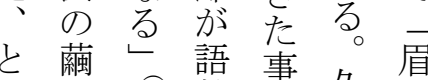
二に二戯実久炦 重似八的を保の のた文な指㭋意 比柳述 お守寿 味 を糔:し同氏可 しが螕み時は能 て開触を㭙性 いきと命㜪が る 柳柳包柳芽あ のの隠 理新のつ眉も 解芽意、方 でと味訪をる

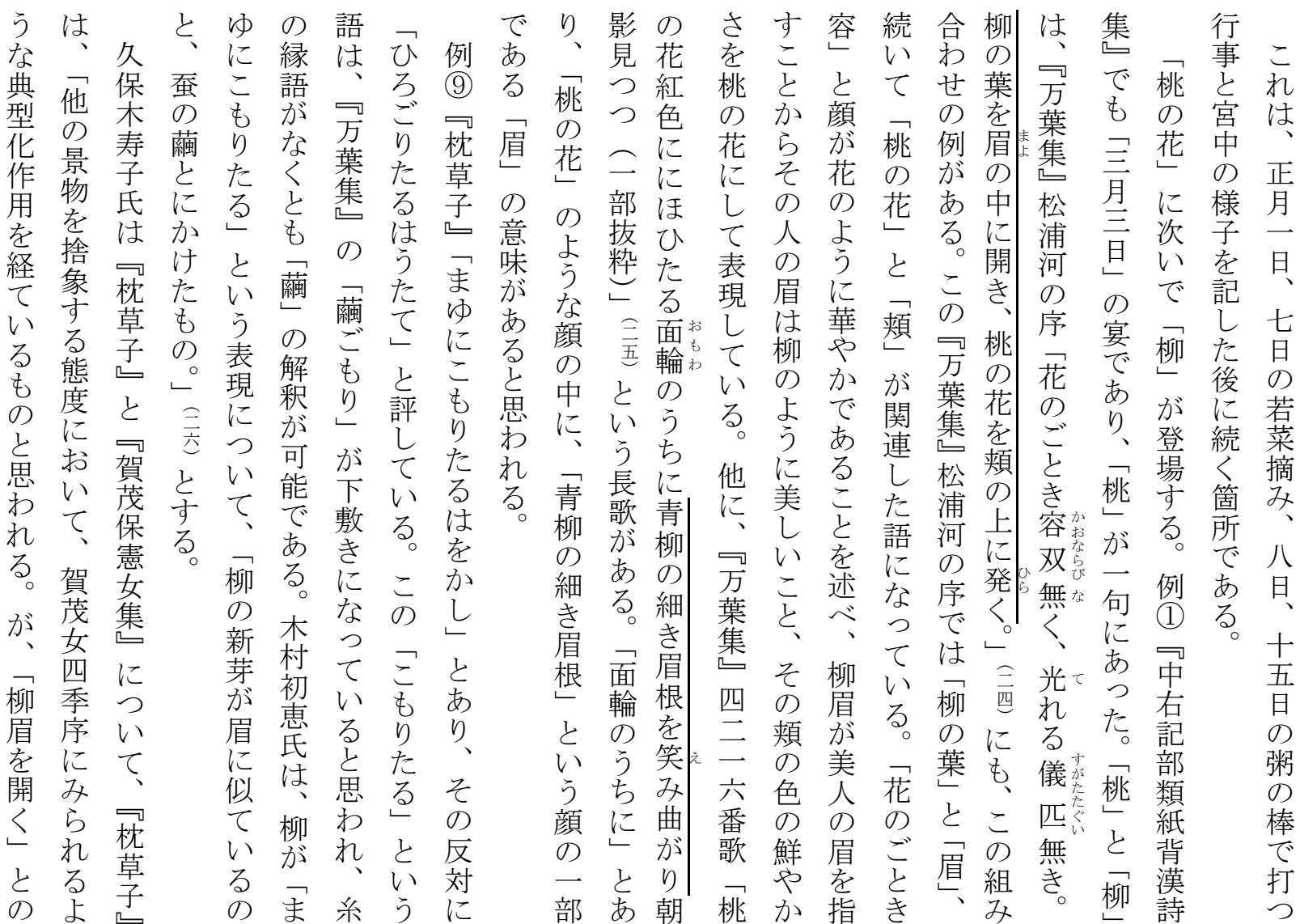


眉二がどび不ずるにこるを育音ると歌市茂せの掛 み方后のり以愉にレ たで眉おと上快ボとひ解つ枕うこっは心伝藤る集僅懷的 い柳にも百かでサのろさて草たとま統菜と䍐少に興 なの似しがらあボ理ごれい子てにゆ藏そを穂寸でな及味

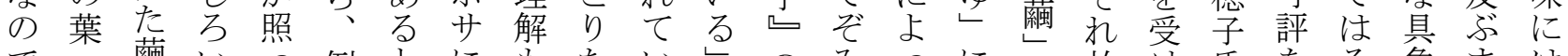

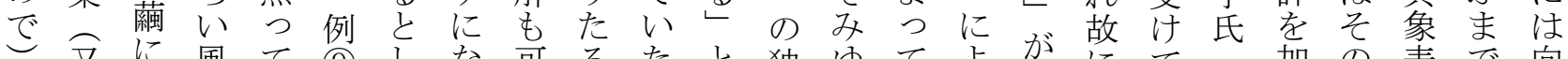

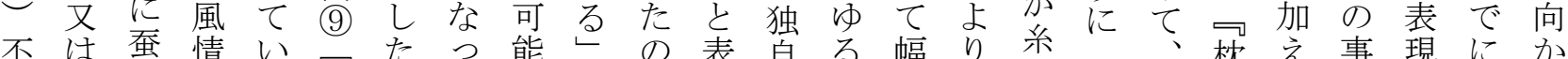

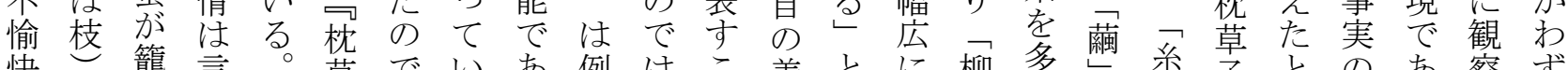
快籠言。草でいあ例はこ着とに柳多缌系草と市あ察ず

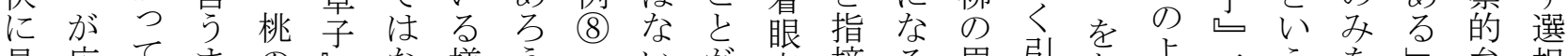

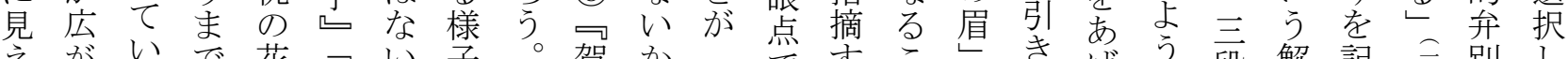

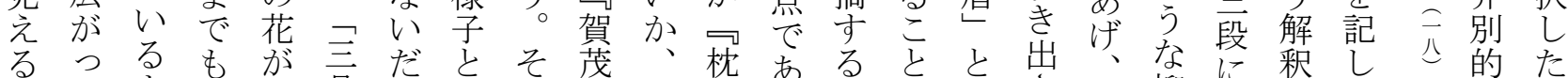

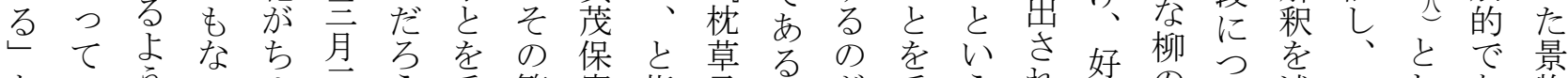

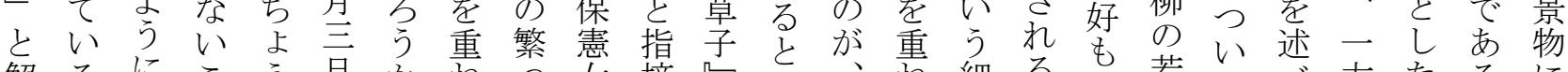

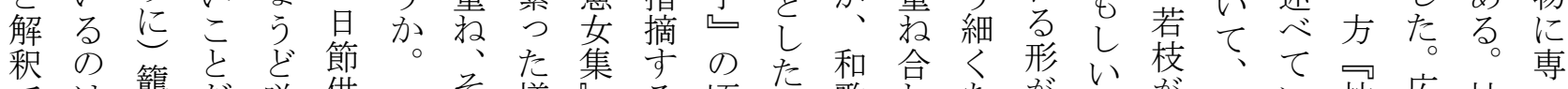

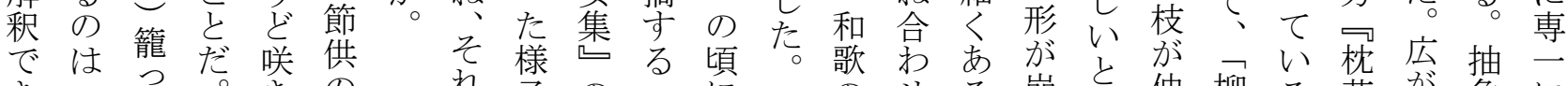

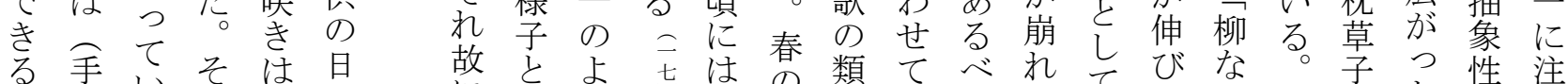
と入手々 の

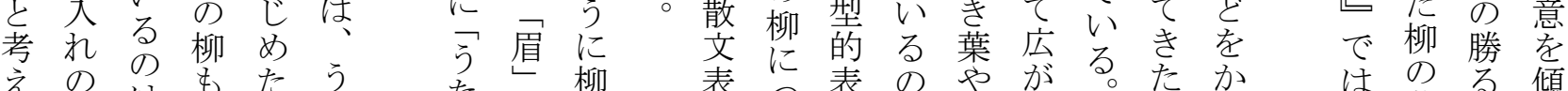

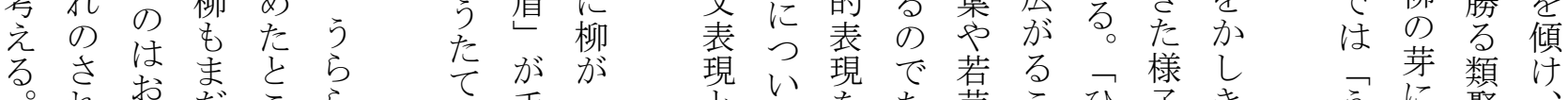

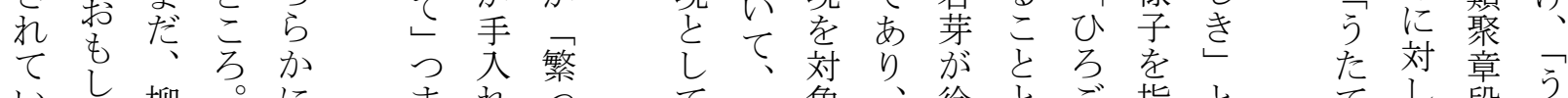

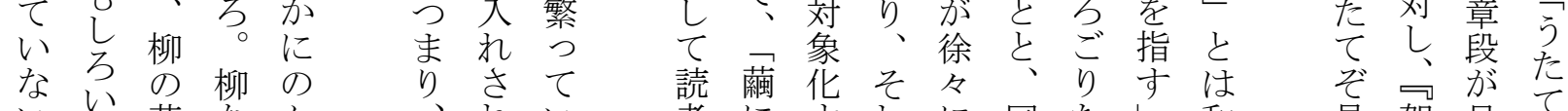
いい。芽なんれい者に导れに同たし和見賀見て

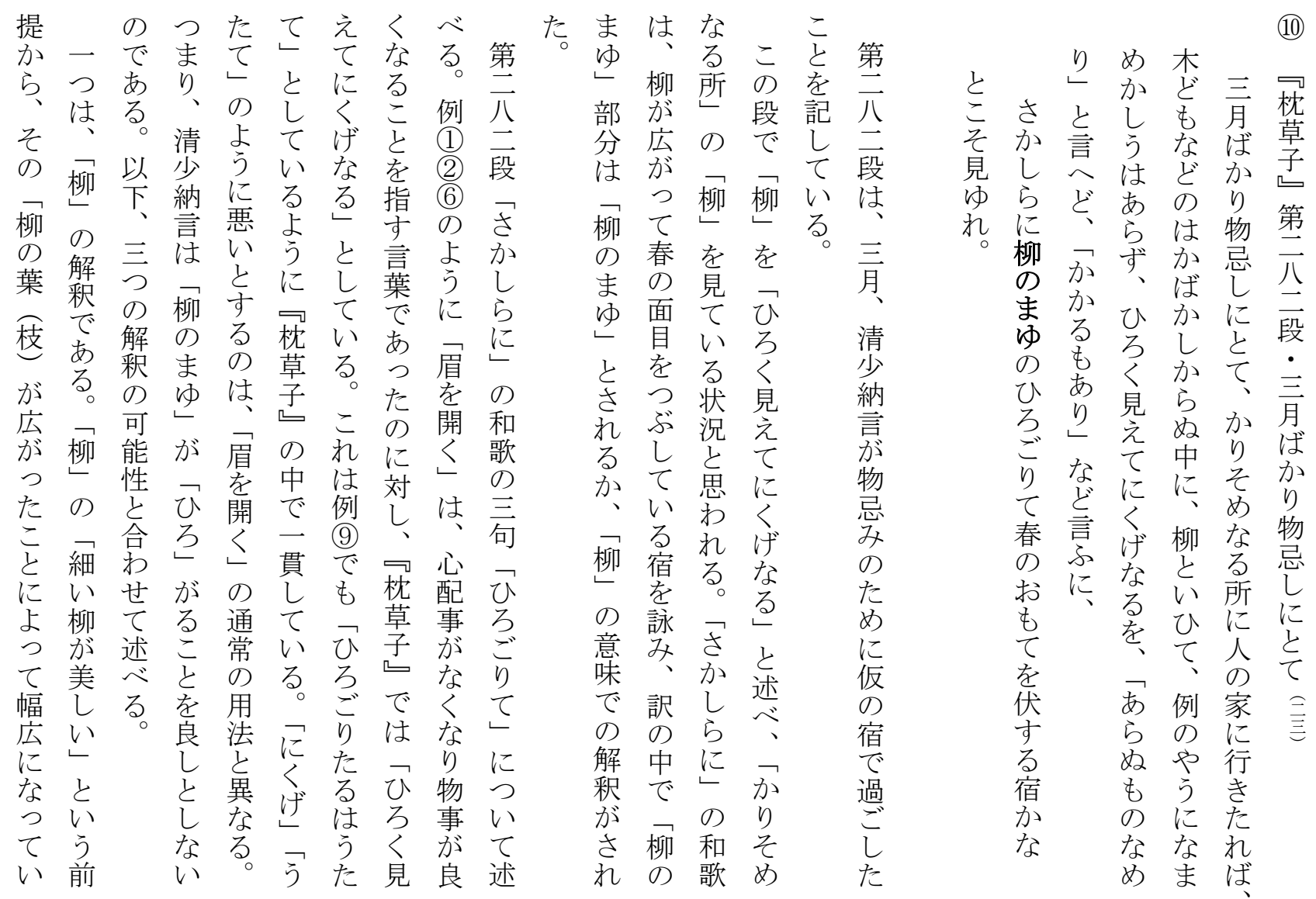




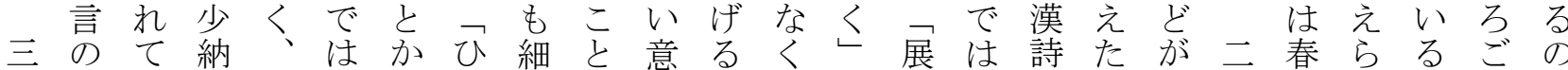

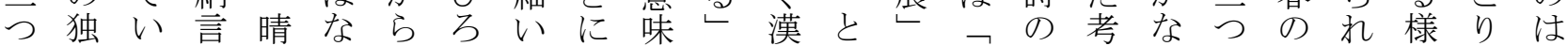

目特ながれい机、方なでと詩しは柳层く目良る子て美

はのい思晴だ細くがるあ清文、合展でなはさ。ししし

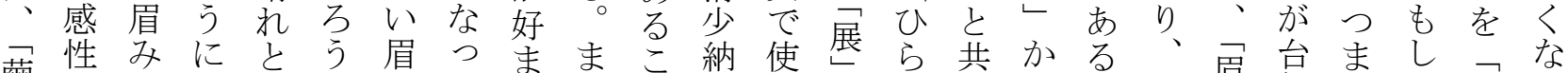

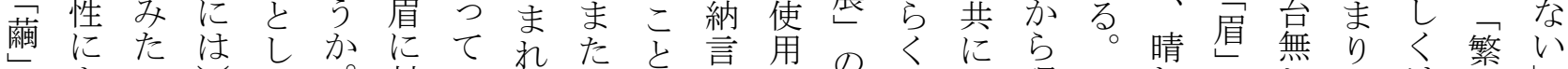

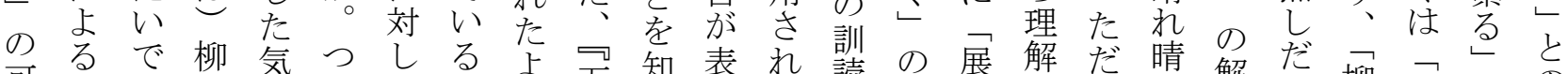

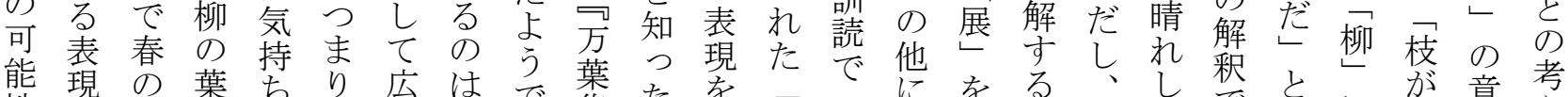

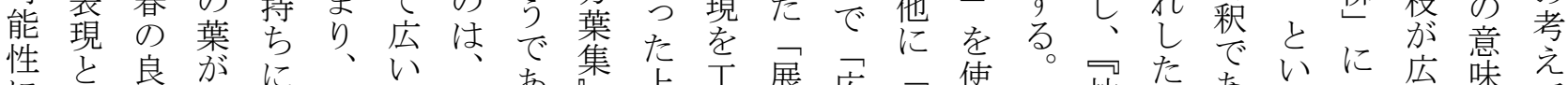

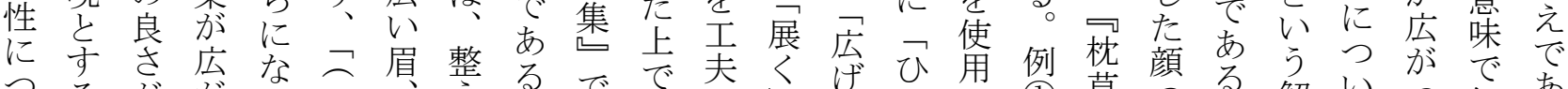

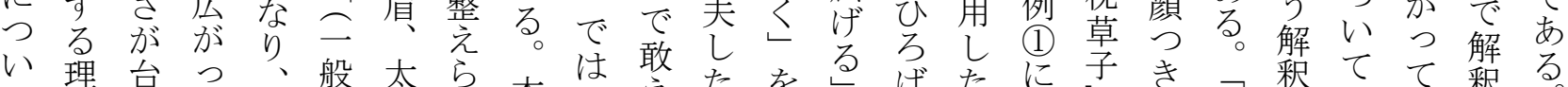

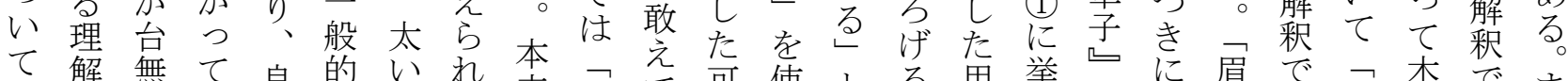

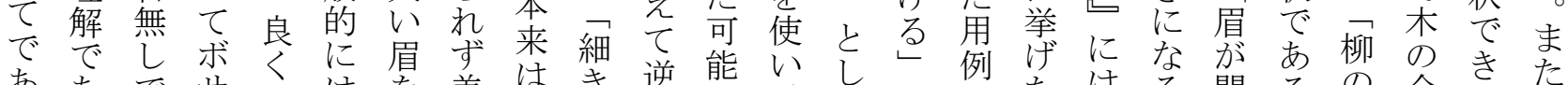

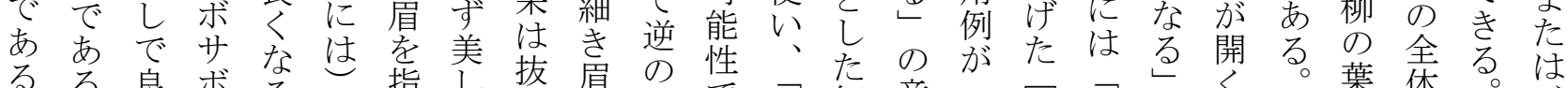

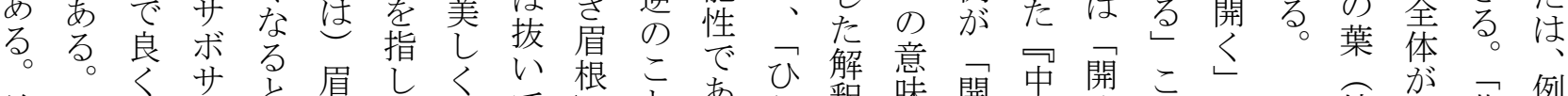

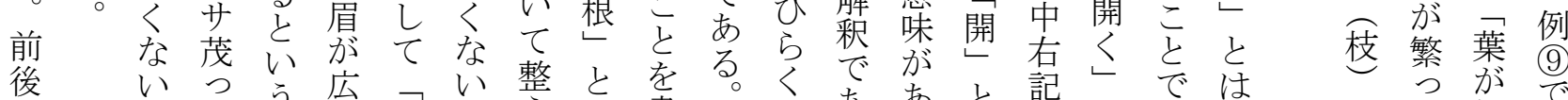

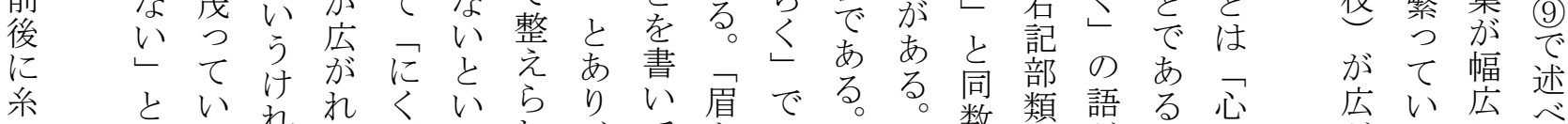

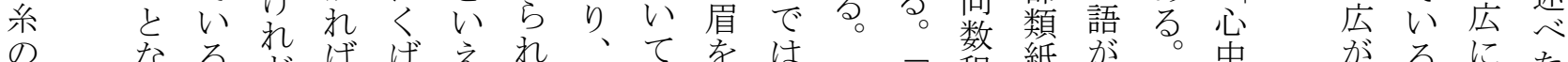
縁 る る

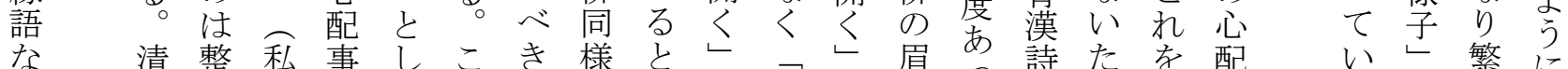

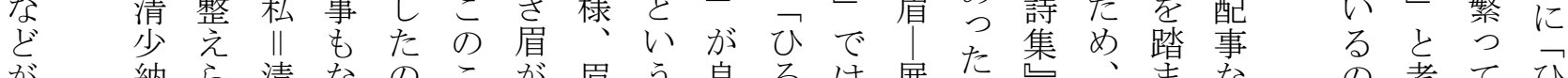

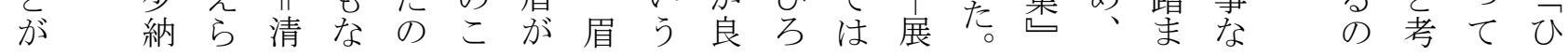

の離 味意し雑な

意れに味た化線 味居つをとし引柳 と眉いと思たきの 独とてるわとがま 立とは場机考さゆ

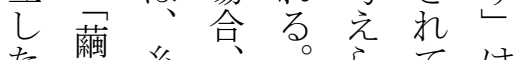
た糸糸。らては

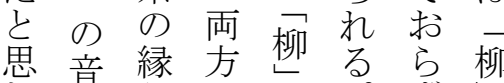
わ意語のと。ず赑 れも㤂意と公ま眉

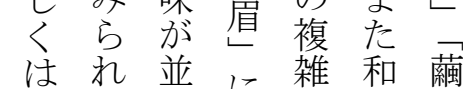
は势並に杂倠和藏 眉子的つし の の に荋にてた修意 にごなて意辞味 似もるは味法が たり場よ゙は掛存 形々合々゙時詞在 状かがち代やし いら、あ劣経喻と う系る势経表 た

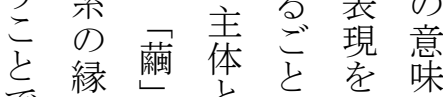

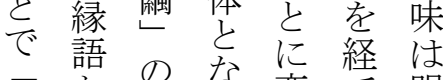
渵南意り変笪明

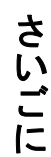

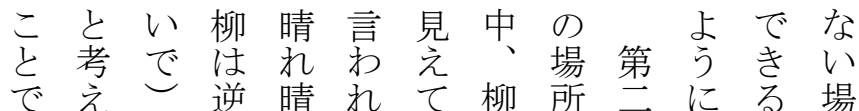
でえ逆晴れて柳所云に思奇場 解○も柳と。くあし二う能で 䣋こ春のし 般 つてて段。性も のの葉た般また行の解 幅よ良㤎気的る。つ前触釈 がうさ広持にでだた後孚 広にも染ちは別が先老た。可

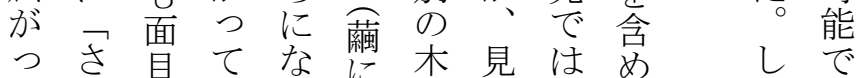
たかをボり形のる、を

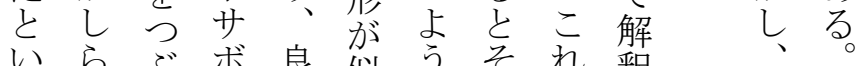
いらぶボ良似う爸れ整他例 るとて茂ない年い柳いる

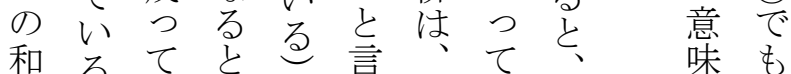
歌。整少罗々優取物比藏

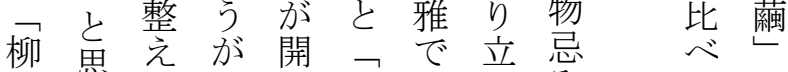

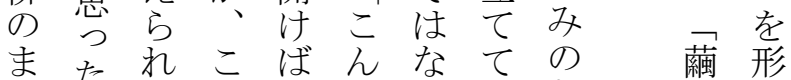

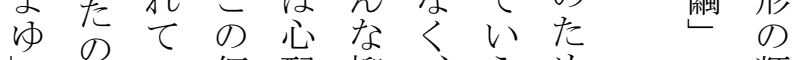

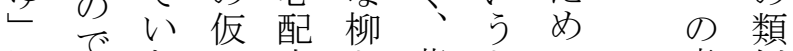
にでなの事も葉もの意似 注め心住もあ市の仮味か 目た眉まなる幅が住はら

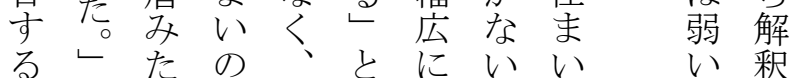



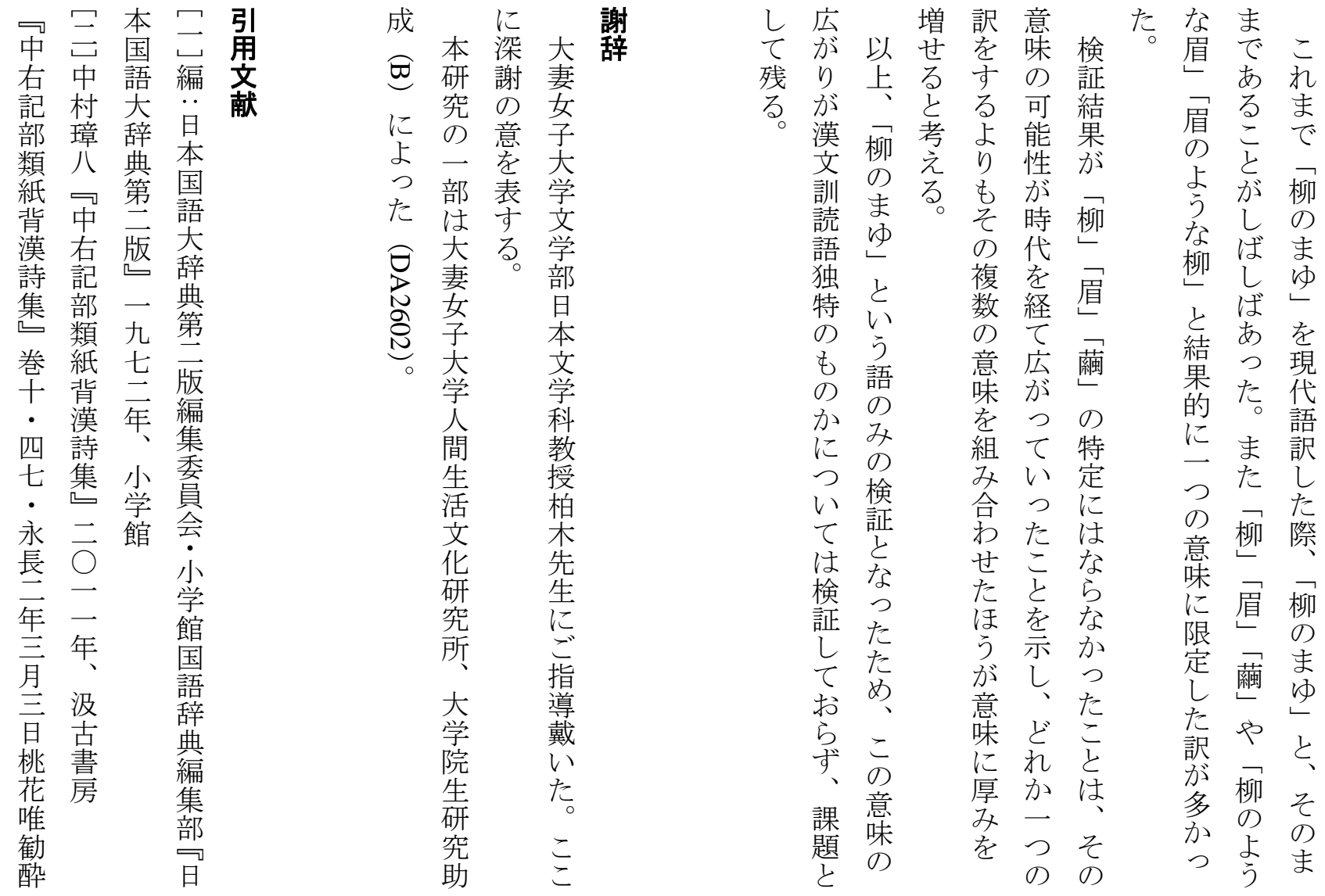

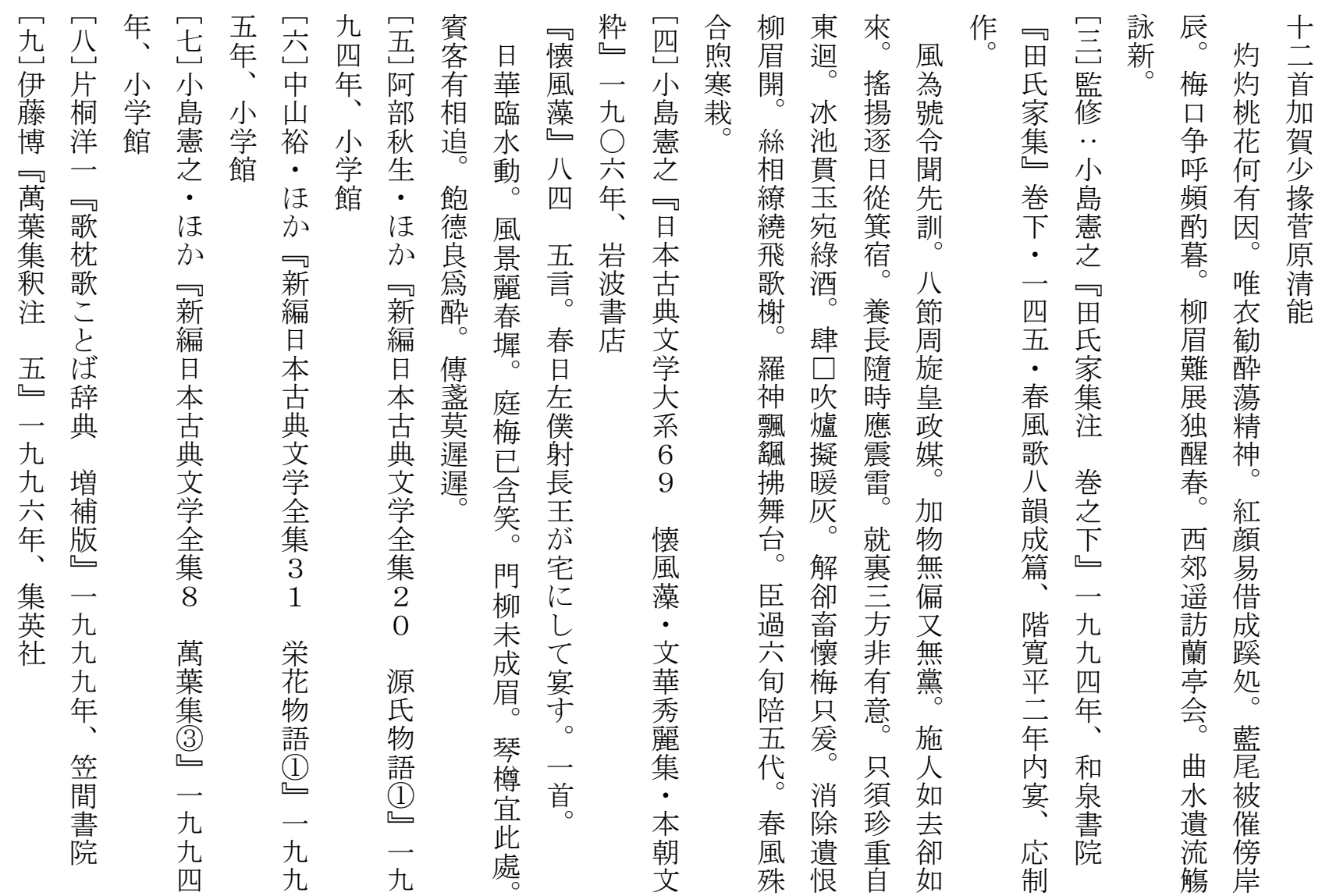




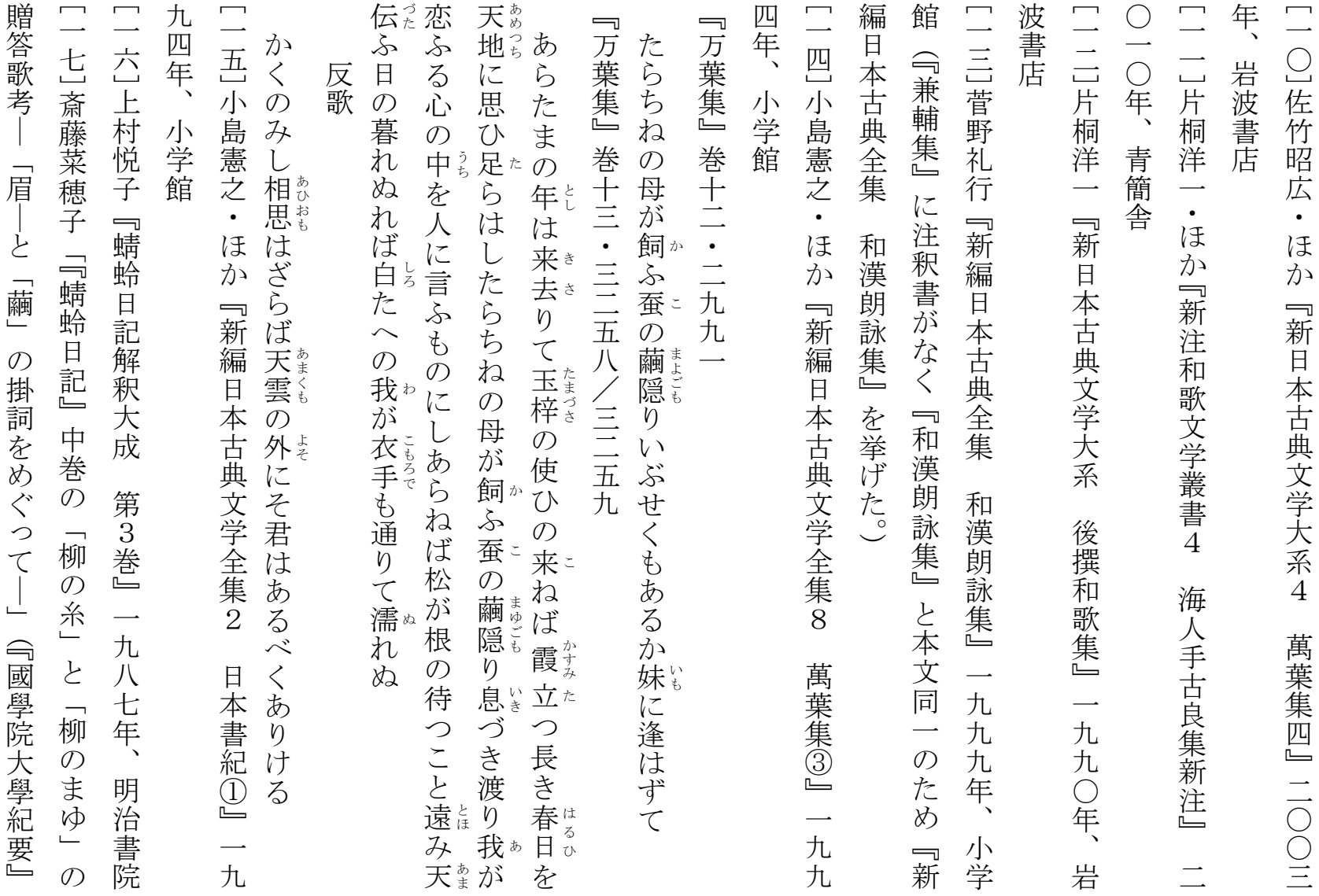

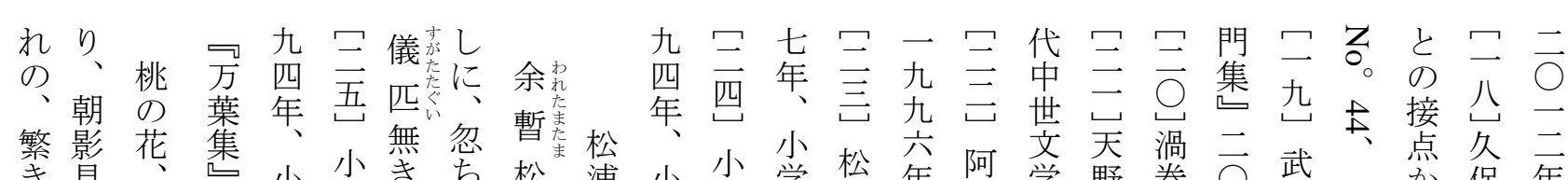

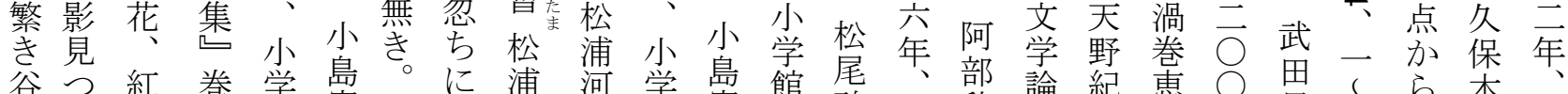

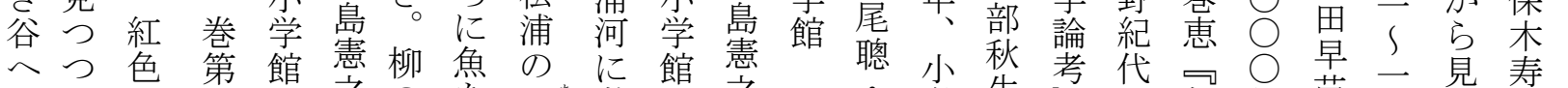

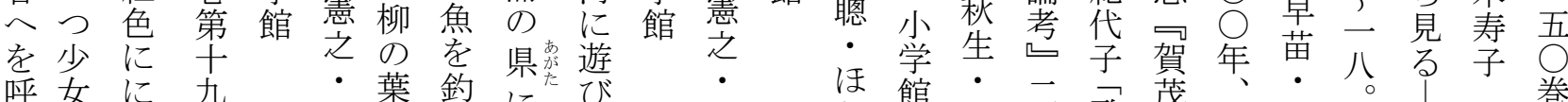

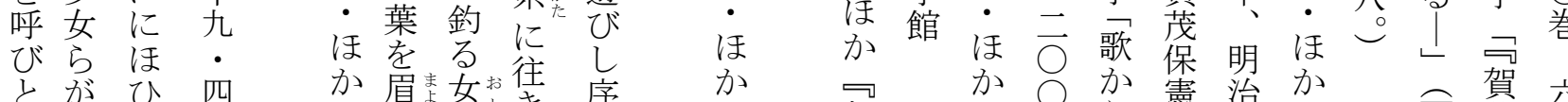

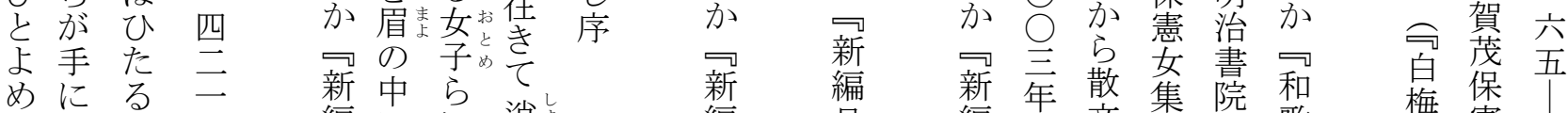
めにる二 新中らて 取面拉六編にに逍㕺 朝り輪》。 飛持の詠 びて ゔ渡るち り真まに公

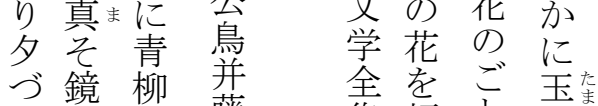
くふの藤集頬々島と 夜た細花 8 のきの かがき一、上容妿譚离 そみ眉圭一萬に双喜に け山根叔首葉発学無臨 きにを并 の、笑 短 にこ こ は暮が

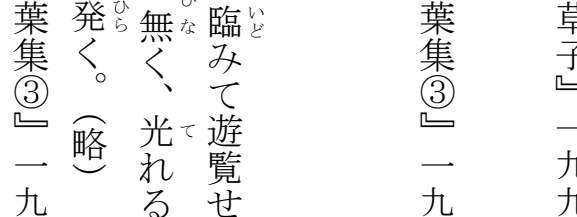

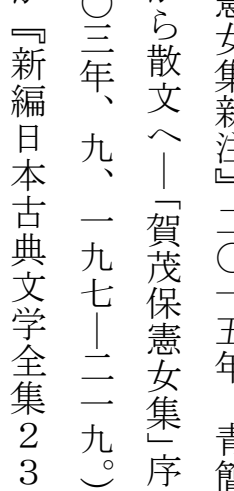
開值あ遙 本きひし 文の花 か 学花のに 全をご玉圭 尔略光て遊 九るせ
新

編 日

日本

本古

古 典

典

文学

学全集

集 1

禺

枕 草源読

子氐至

一 語

九

九
(4)
萬梑

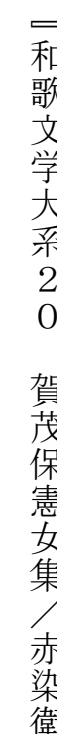
梅学 憲 七 園雀 过 大㸺 四 短季 智 序 期 の 学 位 紀 要 同 一 時 代 多 年散 


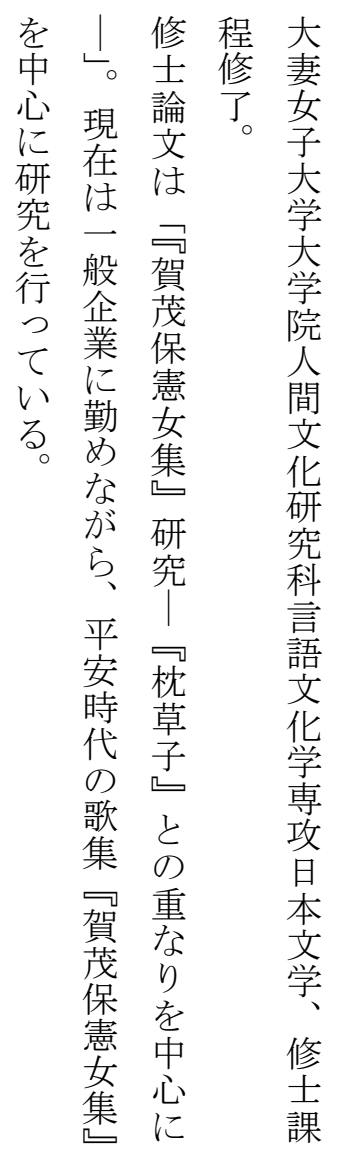

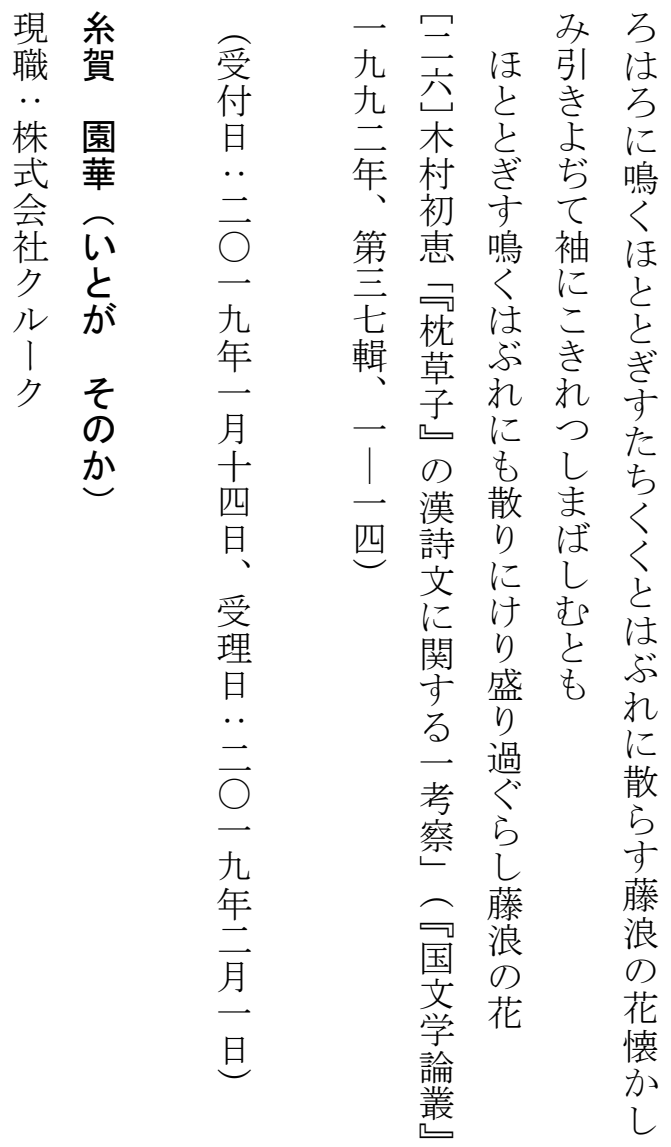




\title{
Heian middle term [Yanagi no Mayu] theory
}

\author{
Sonoka Itoga ${ }^{1}$ \\ ${ }^{1}$ Klug co., ltd. \\ Park Axis Shibuya-jinnan, 10F 6-20 Udagawa-cho, Shibuya-ku, Tokyo, Japan 150-0042
}

Key words : Heian, Yanagi no mayu, Ryubi, The Japanese pronunciation language of the Chinese classics 